\title{
ロータ系の任意振れ回り軌道における外力の解析に向けた磁気軸受装置の開発
}

\author{
加藤 潤也 ${ }^{* 1}$ ，藪井 将太*2，高木 賢太郎 ${ }^{* 2}$, 井上 剛志 ${ }^{* 2}$
}

\section{Development of magnetic bearing device for analysing external forces in arbitrary trajectory to rotor system}

\author{
Junya KATO ${ }^{* 1}$, Shota YABUI ${ }^{* 2}$, Kentaro TAKAGI $^{* 2}$ and Tsuyoshi INOUE ${ }^{* 2}$ \\ ${ }^{* 1,{ }^{*}}$ Department of Mechanical Engineering, Nagoya University \\ Furo-cho, Chikusa-ku, Nagoya-shi, Aichi 464-8603, Japan
}

Received: 21 May 2017; Revised: 18 October 2017; Accepted: 4 March 2018

\begin{abstract}
In design of rotating machines, analysis of external force is important for stable rotating operation. The various external forces such as unbalance force, seal contact force and rotor dynamic fluid force effect on the rotor system, dynamic characteristics of rotating system is changed by the external forces. The external force can vary depending on a rotor trajectory. In previous studies, a mathematical model of the dynamic characteristics had been formulated for small amplitude orbit around the equilibrium point for the rotor trajectory. However, the formulation hasn't been yet established in the rotor trajectory with large amplitude or eccentricity caused by the external forces. In this study, an experimental system using active magnetic bearing (AMB) is developed to achieve the formulation. The system can generate any arbitrary trajectory assuming various external forces and the rotor system follow the generated trajectory. The system can estimate the external force at the same time. Current flowing through coil of the AMB is controlled by a controller designed based on the frequency response to follow the arbitrary orbit. Then, the external forces are estimated from the control signal by the disturbance observer. Experiments were performed by assuming unbalance forces generated in the elastic rotor. From the results it was confirmed experimentally that high precision tracking control and estimation of external force are possible. The various rotor trajectory under the action of the external forces can be repeated by using the system, and the external force can be analyzed by the experimental data.
\end{abstract}

Keywords : Active magnetic bearing, Tracking control, Disturbance estimation, Loop shaping, Disturbance observer

\section{1. 緒言}

航空機エンジンや圧縮機などに用いられる回転機械において，安定な回転動作を持続することが重要である. 安定な回転動作を実現するために必要な技術の一つとして， ロータ系に作用する外力の解析が挙げられる. 外力 の作用下では回転軸が振れ回りや偏心を持った軌道となり，その安定性に悪影響を与える可能性がある．現状， 不釣り合い力, シール接触力，そしてロータダイナミック流体力といった外力に対し，回転軸の平衡位置周りの 微小振幅運動に対しては定式化できている（兼森他，1989, Yun and Brennen, 2002, Andrés and Delgado, 2012, 西 嶋他, 2014, Andrés and Jeung, 2016)．しかしながら，回転軸の軌道がクリアランスの半分程度まで大きくなった 場合，また中心からずれて偏心を持った場合など，大きく変化したときにロータ系に作用している外力の定式化 はできていない，先行研究では，そのような状態でロー夕系に作用する外力を解析するため，回転動作中に外力 を加えてデータを取得する装置の開発が行われている（Andrés and Jeung, 2015, Andrés et al., 2016)。その実験装 置では, ベアリングカートリッジに加振器を設置し, 装置を直接振動させることで外力を加えている.

本研究では，ロータ系に作用する様々な外力を解析するため, 能動型磁気軸受 (Active magnetic bearing: 以 下，AMB）を用いた実験装置を開発している，AMB は電磁石に流れる電流を制御することにより，ロータ系の 回転軸の位置を制御できる. AMB を用いて外力を推定する先行研究も存在するが，回転軸の中心位置周りの微 小振幅運動の解析が主である（江口他, 2002, Tokunaga et al., 2016)。そこで, AMB に流寸電流を制御し，大振幅 や偏心を持った任意の軌道を簡便に生成，さらにセンサ等を用いずに制御信号からロータ系に加わった外力を直

No.17-00227 [DOI:10.1299/transjsme.17-00227], J-STAGE Advance Publication date : 13 March, 2018

${ }^{* 1}$ 名古屋大学 工学研究科（广 $464-8603$ 愛知県名古屋市千種区不老町）

*2 正員, 名古屋大学 工学研究科

E-mail of corresponding author: yabui@nuem.nagoya-u.ac.jp 
接推定することを目指して装置の開発を行っている，本実験装置を用いて，回転軸の軌道が大振幅や偏心を持っ たときに作用する，不釣り合い力，シール接触力，そしてロータダイナミック流体力といった外力の解析に貢献 できると期待される.

本論文では，開発した実験装置を用いて，回転軸を大振幅の振れ回り軌道に追従させ，そのときにロータ系に 作用する外力を推定した実験結果を報告する. 本論文において対象としたロータ系は, 汎用的に用いることを目 指し，回転軸の弾性モードに起因寸る振動も考慮した実験を行えるように弾性ロータとした，そのロータ系にお いて，AMBに流す電流を制御するコントローラを設計し，回転軸を任意軌道に追従させた上で，外力を推定す ることを試みた．まず，ロータ系の弾性モードによる振動などを補償するフィードバックコントローラを周波数 整形によって設計した，そして，目標軌道を生成するためのフィードフォワードコントローラと，外力の補償と 推定をするための外乱オブザーバを制御対象の周波数特性を基に設計した. 本実験装置で用いる制御系は周波数 応答を用いて設計しているので，設計の見通しがよく，汎用性が高いと考えられる。この実験装置を用いて，ク リアランスの約 $50 \%$ の振幅となる振れ回り軌道に対して回転軸を追従制御させ，外力として与えた既知の不釣 り合い力を推定する実験を行ったところ, サブマイクロメートルオーダーの精度で回転軸を追従させることがで き，外乱オブザーバの出力から不釣り合い力を誤差 $10 \%$ 以下の精度で推定できることを実機にて確認した.

\section{2. 磁気軸受・ロータ系モデル}

本研究で扱う吸引型磁気軸受モデルの構造を図 1 に示す．回転軸の上端が自動調心玉軸受で支持されてい る.また回転軸はユニバーサルジョイントを介して回転運動を与えるモータにつながれている．回転軸には慣性 ロータが取り付けられており, 角運動量を生み出す. また, 慣性ロータには不釣り合い力を調整できるの重りを 付着させることができ, 自由に不釣り合い力を調節できる. 回転軸の運動は, 下端付近に設置された AMB が発 生する吸引力によって制御される. 電磁石は, 外側の十分固い枠に固定されており変動はないものとする. 回転 軸には位置センサが設置されており，回転軸の位置信号をデジタルシグナルプロセッサ(Digital signal processor: 以下，DSP)に送信している. DSP には比例微分制御則(以下，PD制御則)が書き込まれており，その制御則にし たがって決定された值の電流が電磁石に流れる. また, 提案したモデルには安全のために補助軸受が設置されて おり, 外乱が加わり回転軸が想定を超えて大きく振れ回った場合, 回転軸が位置センサや電磁石に接触する前

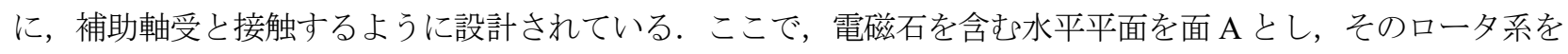
上から見たときの断面を図 2 に示す.

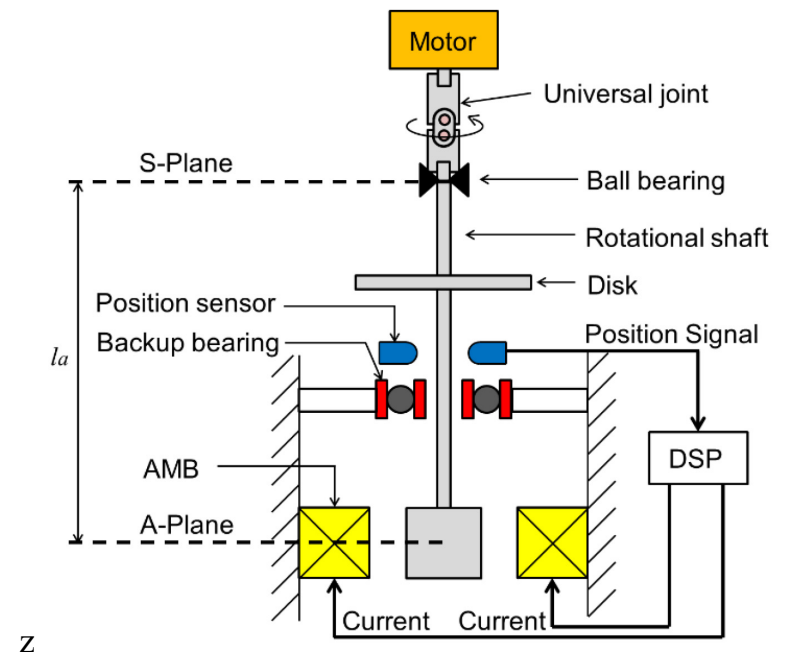

Fig. 1 Schematic of rotor system supported by a magnetic bearing

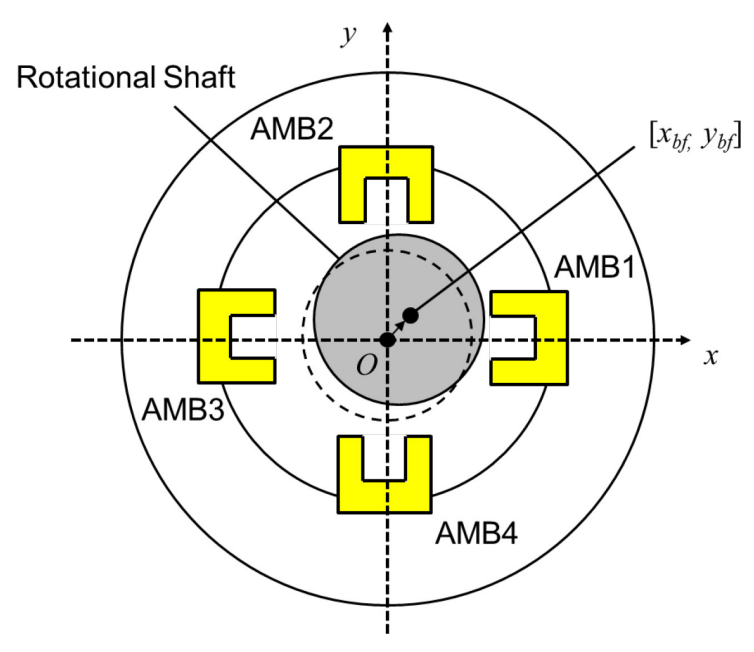

Fig. 2 Surface of plane A viewing from above

ここで，回転軸の上端の玉軸受位置を支点とした回転運動を考える. 本実験装置において, 回転運動の回転角が 微小であるため, $\mathrm{A}$ 平面での回転軸の剛体モードの運動方程式は以下のように近似できる. 


$$
\left.\begin{array}{c}
\frac{I}{l_{a}^{2}} \ddot{x}_{b f}+\frac{I_{p} \omega}{l_{a}{ }^{2}} \dot{y}_{b f}=F_{x}+d_{x} \\
\frac{I}{l_{a}{ }^{2}} \ddot{y}_{b f}-\frac{I_{p} \omega}{l_{a}{ }^{2}} \dot{x}_{b f}=F_{y}+d_{y}
\end{array}\right\}
$$

ここで， $x_{b f}$ と $y_{b f}$ はそれぞれ変位を表し $F_{x}, F_{y}$ 及び $d_{x}, d_{y}$ は $x, y$ 方向の電磁石による吸引力及びロータ 系に作用する外力である。 また， I ， I $p$ は回転軸の慣性モーメントと極慣性モーメントであり，慣性モーメン トの回転中心は玉軸受とする． $l_{a}$ は上端の玉軸受位置から A平面までの距離であり $\omega$ は回転軸の自転角速度で ある，電磁石による吸引力 $F_{x}, F_{y}$ は電流の 2 乗に比例し，エアギャップに定数 $\delta_{x}, \delta_{y}$ を加えたものに反比例 する (井上他, 2005). 図 2 に示す通り, AMB は4つの電磁石により構成されている. 電磁石による吸引力 $F_{x}, \quad F_{y}$ は図に示す通り，それぞれ電磁石 1 と 3 及び，電磁石 2 と 4 より発生する吸引力の和によりあらわさ れ, 次式になる.

$$
\begin{aligned}
& F_{x}=k_{x}\left(\frac{i_{1}}{R-x_{b f}+\delta_{x}}\right)^{2}-k_{x}\left(\frac{i_{3}}{R+x_{b f}+\delta_{x}}\right)^{2} \\
& F_{y}=k_{y}\left(\frac{i_{2}}{R-y_{b f}+\delta_{y}}\right)^{2}-k_{y}\left(\frac{i_{4}}{R+y_{b f}+\delta_{y}}\right)^{2}
\end{aligned}
$$

ここで， $i_{1} \sim i_{4}$ はそれぞれ電磁石 1 から 4 に流れる電流を表し， $R$ は AMB の平衡クリアランスを表す.また， $k_{x}, \quad k_{y}$ は吸引力を表す電磁石定数， $\delta_{x}, \delta_{y}$ は電磁石とロータ系のギャップ補正值である. 本実験装置のよう に，位置を測定するセンサ位置と制御を行う電磁石の位置が異なるとき，誤差を生じる可能性があるため，要す ればそれを補正するパラメータとして導入している，なお，本論文では自転速度 $1000 \mathrm{rpm}$ 前後の低回転速度域 での運転を考えるため，ジャイロ項の影響は小さいとして無視する．その場合には回転軸の運動方程式は次式で 示すように $x, y$ 方向で独立したものとなる. そのため, 以降の内容では $x, y$ 方向で内容に差異がない場合 には $x$ 方向についてのみ記述することとする.

$$
\left.\begin{array}{c}
\frac{I}{l_{a}^{2}} \ddot{x}_{b f}=F_{x}+d_{x} \\
\frac{I}{l_{a}^{2}} \ddot{y}_{b f}=F_{y}+d_{y}
\end{array}\right\}
$$

\section{3. 振れ回り軌道追従システムの制御設計方針}

AMB による任意の回転軸軌道への追従制御を実現するために，本論文では図 3 に示す AMB 制御系を考え

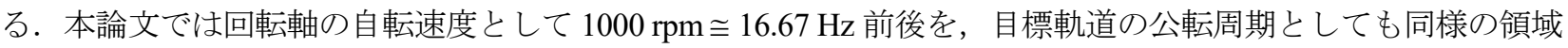
まででの運転を考えることから，制御帯域を $17 \mathrm{~Hz}$ 程度と設定する.

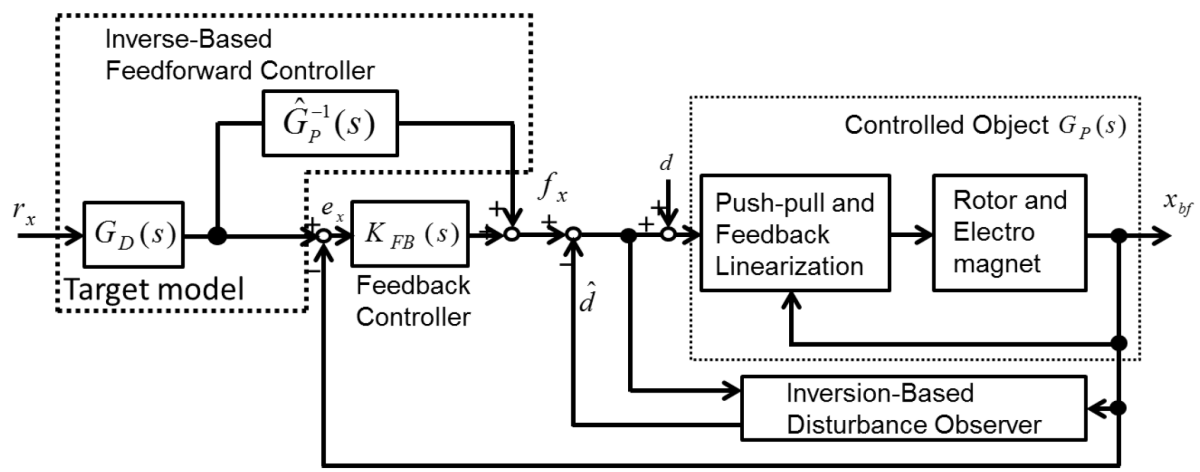

Fig. 3 Block diagram of control system for tracking control 


\section{$3 \cdot 1$ フィードパック線形化}

一般的に AMB で使用する電磁石の吸引力は，式（2）に示されるように非線形な特性を持つ。レギュレータ 制御を目的とした一般的な AMB 制御系では, 線形近似を行い, 非線形性を無視して制御設計が行われることも 多い（電気学会編，1993，日本機械学会編，1995, 井上他，2005)。しかしながら，本論文では AMB ギャップ 内での回転軸軌道の追従制御を目的とするため, 一般的な AMB 制御系の場合と比較して, 非線形性の影響がよ り大きい可能性がある，そこで，本論文ではフィードバック線形化を用いることにより，電磁石のもつ非線形性 を補償することを考える（杉江他，1993， Lindlau and Knospe, 2002, Chen and Knospe, 2005）＜wide>プッシュプルと フィードバック線形化コントローラの概略を図 4 に示す．プッシュプルブロックでは，AMB にて一般的によく 用いられるプッシュプル方式により，次式のように制御入力 $f_{x}$ を電磁石 1 と 3 に対して振り分ける.

$$
\begin{aligned}
& F_{1}=f_{0 x}+f_{x} / 2 \\
& F_{3}=f_{0 x}-f_{x} / 2
\end{aligned}
$$

ここで， $f_{0 x}$ はバイアスカ， $F_{1}, F_{3}$ はそれぞれ電磁石 1 と 3 の目標吸引力である. 次にフィードバック線形化 により, 目標吸引力 $F_{1}, F_{3}$ を実現するために必要な各電磁石への指令電流值 $i_{1}, i_{3}$ を次式のように逆算する.

$$
\begin{aligned}
& i_{1}=\left(R-x_{b f}+\hat{\delta}_{x}\right) \sqrt{F_{1} / \hat{k}_{x}} \\
& i_{3}=\left(R+x_{b f}+\hat{\delta}_{x}\right) \sqrt{F_{3} / \hat{k}_{x}}
\end{aligned}
$$

ここで， $\hat{k}_{x}, \hat{\delta}_{x}$ はフィードバック線形化コントローラ内の電磁石パラメータの設定值を表す. 式 (4) および （5）を式（2）に代入することにより, 制御入力 $f_{x}$ と $x$ 方向の電磁石の吸引力 $F_{x}$ の関係式として次式を得る.

$$
F_{x}=\frac{k_{x}}{\hat{k}_{x}}\left(\frac{R-x_{b f}+\hat{\delta}_{x}}{R-x_{b f}+\delta_{x}}\right)^{2}\left(f_{0 x}+f_{x} / 2\right)-\frac{k_{x}}{\hat{k}_{x}}\left(\frac{R+x_{b f}+\hat{\delta}_{x}}{R+x_{b f}+\delta_{x}}\right)^{2}\left(f_{0 x}-f_{x} / 2\right)
$$

ここで, 電磁石パラメータに関して, フィードバック線形化コントローラ内の設定值 $\hat{k}_{x}, \hat{\delta}_{x}$ が真值 $k_{x}, \delta_{x}$ と等し い場合, 寸なわち $\hat{k}_{x}=k_{x}, \hat{\delta}_{x}=\delta_{x}$ の場合には, 式 (6) は $F_{x}=f_{x}$ となり線形な制御入力が実現される. 先行研 究を参考にして，本論文では $\hat{k}_{x}$ については実験的同定值を， $\hat{\delta}_{x}$ については 0 を用いた（Kato et al., 2016）. そ の場合の磁気力 $F_{x}$ は以下のようにあらわすことが出来る.

$$
\begin{aligned}
F_{x} & =\frac{k_{x}}{\hat{k}_{x}}\left(\frac{R-x_{b f}}{R-x_{b f}+\delta_{x}}\right)^{2}\left(f_{0 x}+f_{x} / 2\right)-\frac{k_{x}}{\hat{k}_{x}}\left(\frac{R+x_{b f}}{R+x_{b f}+\delta_{x}}\right)^{2}\left(f_{0 x}-f_{x} / 2\right) \\
& \approx A_{0} x_{b f}+B_{0} f_{x} \\
A_{0} & =-4 f_{0 x} \frac{k_{x}}{\hat{k}_{x}} \frac{R \delta_{x}}{(R+\delta)^{3}}, \quad B_{0}=\frac{k_{x}}{\hat{k}_{x}}\left(\frac{R}{R+\delta_{x}}\right)^{2}
\end{aligned}
$$

式（7）を式（3）に代入することにより次式を得る.

$$
\frac{I}{l_{a}^{2}} \ddot{x}_{b f}=A_{0} x_{b f}+B_{0} f_{x}+d_{x}
$$

ここで, 両辺をラプラス変換することにより制御入力 $f_{x}$ から変位 $x_{b f}$ までの伝達関数を考えると, プッシュプル とフィードバック線形化まで含めた制御対象の剛体モードの伝達関数モデルとして次式を得る. 


$$
G_{P R}(s)=\frac{\left(l_{a}^{2} / I\right) B_{0}}{s^{2}-\left(l_{a}^{2} / I\right) A_{0}}
$$

なお，実際の制御対象の特性には弾性モードも含まれることから，プッシュプルとフィードバック線形化まで含 んだ制御対象の実際のモデルは $G_{P}(s)$, 剛体モードのみのモデルは $G_{P R}(s)$ と表記することとし, 両者は異なる ものとする. また，外力 $d_{x}$ から変位 $x_{b f}$ までの伝達関数を考えることにより次式を得る.

$$
G_{d x}(s)=\frac{\left(l_{a}^{2} / I\right)}{s^{2}-\left(l_{a}^{2} / I\right) A_{0}}
$$

式（9）と式（10）を比較すると制御入力 $f_{x}$ と外力 $d_{x}$ それぞれから変位 $x_{b f}$ までの入出力関係が異なることがわ かる. このような入出力関係の間での差異は, 後述する逆モデル型外乱オブザーバの設計を考える際に好ましく ない. そこで本論文では, 制御入力と外乱入力からの入出力関係を共にモデル $G_{P R}(s)$ とするために制御対象に対 する見かけ上の外乱入力 $\bar{d}_{x}=d_{x} / B_{0}$ を新たに定義する. なお，制御設計に用いるモデル $G_{P R}(s)$ のパラメータは 閉ループ同定により実験的に求める. 制御対象の閉ループ同定実験については後の実験の章にて詳細に述べる.

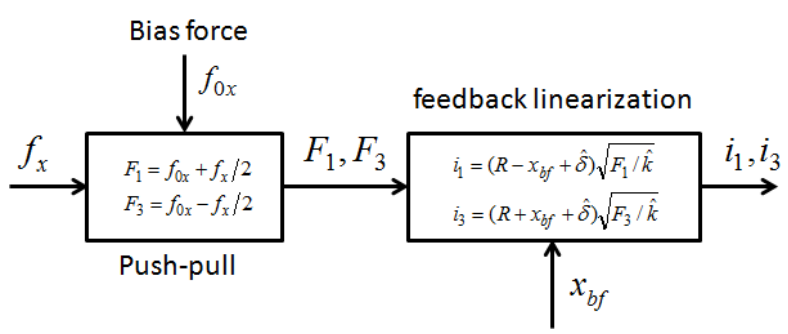

Fig. 4 Push-pull and feedback linearization

\section{$3 \cdot 2$ フィードバックコントローラ}

回転軸の高精度追従を実現するためフィードバックコントローラを用いる. 本実験装置では弾性ロータを対象 とするので，フィードバックコントローラは弾性モードを励起しないように設計する必要がある．また，前述し た回転速度を考慮し $17 \mathrm{~Hz}$ までの軌道に追従できるように設計する. 本研究ではフィードバックコントローラと して式（11）に示すような PD 制御とノッチフィルタを組み合わせたものを用いる.

$$
K_{F B}=K_{P D}(s) F_{F B}(s)=\left(k_{P}+k_{D} \frac{s \omega_{c_{-} P D}}{s+\omega_{c_{-} P D}}\right) \prod_{i=1}^{2}\left(H_{0 i} \frac{s^{2}+\left(\omega_{n i} / Q_{n i}\right) s+\omega_{n i}{ }^{2}}{s^{2}+\left(\omega_{d i} / Q_{d i}\right) s+\omega_{d i}{ }^{2}}\right)
$$

$\mathrm{PD}$ ゲイン $k_{P}, k_{D}$ については極配置により閉ループの極が重根, そして制御帯域が $17 \mathrm{~Hz}$ となるように設計する

(野波他, 1998)。ノッチフィルタに関しては実験的に同定したフィードバック線形化まで含んだ制御対象の周波 数応答をもとに，制御信号による弾性モードの励起を防ぐため，制御系のゲインを落とすように設計する.

\section{$3 \cdot 3$ 逆モデル型外乱オブザーバ}

本実験装置の目的は，回転軸を任意軌道へ高精度に追従した上で，ロータ系に作用する外力を推定することで ある. そのため, 外力作用下において, 回転軸の軌道追従制御に対する外力の影響を補償し，かつ外力を推定す ることが求められる．そこで，本論文では，逆モデル型外乱オブザーバ（Noshadi et al., 2015）を用いて外力補償 と外力推定の両方を行うことを考えた. 図 5 に逆モデル型外乱オブザーバのブロック線図を示す. 


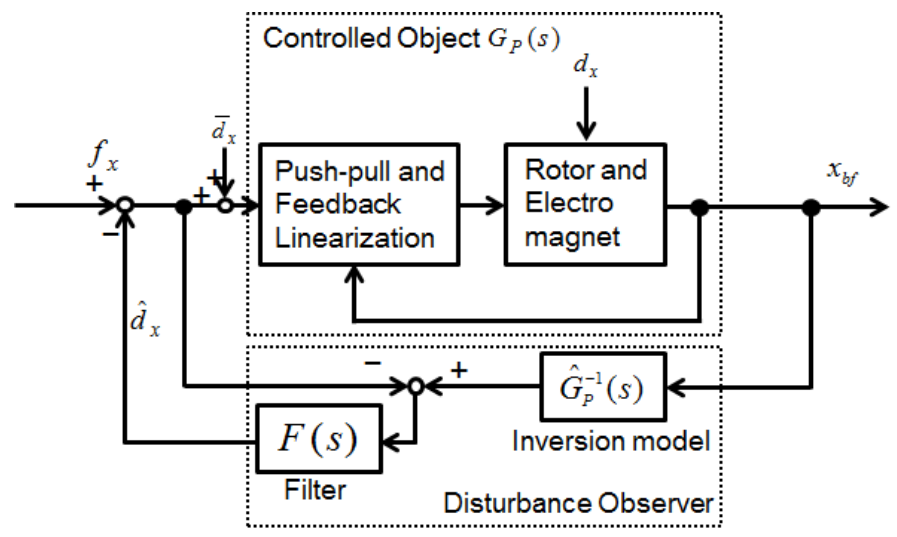

Fig. 5 Block diagram of inner loop system rerated to inversion based disturbance observer

オブザーバ内の逆モデル $\hat{G}_{P}^{-1}(s)$ には実験的に同定した制御対象の剛体モードモデル $G_{P R}(s)$ の逆を用いる. 次にフィルタ $F(s)$ の設計指針について説明する. まず，逆モデル $\hat{G}_{P}{ }^{-1}(s)$ がプロパーでない伝達関数をもつた め, フィルタ $F(s)$ はオブザーバ全体がプロパーとなるような次数である必要がある. 次に，フィルタと外乱の 推定・相殺性能の関係について考える. 図のような逆モデル型外乱オブザーバを用いた際の，制御対象への見か け上の外乱入力 $\bar{d}_{x}$ から推定外乱 $\hat{d}_{x}$ までの入出力関係は次式のようになる.

$$
\hat{D}_{x}=H_{d}(s) \bar{D}_{x}=\frac{\hat{G}_{P}^{-1}(s) G_{P}+K_{F B}(s) G_{P}(s)}{1+F(s)\left\{\hat{G}_{P}^{-1}(s) G_{P}-1\right\}+G_{P}(s) K_{F B}(s)} F(s) \bar{D}_{x}
$$

ここで, $F(s) \approx 1$ とすると $H_{d}(s) \approx 1$ となることから, 外乱推定の精度に関してはフィルタ $F(s)$ を 1 に近い特性 とすることで向上させることが出来ることがわかる. 最後に，フィルタの安定性への影響を考える. 図 5 の推定 外乱 $\hat{d}_{x}$ のフィードバックループを切った場合の制御入力 $f_{x}$ 及び外乱入力 $\bar{d}_{x}$ から外乱才ブザーバの出力 $\hat{d}_{x}$ まで の入出力関係は次式のようになる.

$$
\hat{D}_{x}=F(s)\left\{\hat{G}_{P}^{-1}(s) G_{P}(s)-1\right\} F_{x}+F(s) \hat{G}_{P}^{-1}(s) G_{P}(s) \bar{D}_{x}
$$

ここで，弾性モードの影響が小さい低周波領域である制御帯域と弾性モードの影響が大きい弾性モードピーク位 置近近傍の $2 つ の$ 周波数領域に分けて考える。まず，制御帯域では剛体モードが支配的である一方で，逆モデル $\hat{G}_{P}{ }^{-1}(s)$ には剛体モードモデル $G_{P R}(s)$ を用いるから， $\hat{G}_{P}{ }^{-1}(s) G_{P}(s) \approx 1$ となりこの場合には先ほどと同様に $\hat{D}_{x} \approx F(s) \bar{D}_{x}$ となる. そのため $F(s) \approx 1$ のような特性であっても推定外乱 $\hat{d}_{x}$ をネガティブフィードバックした場 合にも外乱入力を打ち消寸の夕で安定性に関しては大きな問題は生じない. 一方，弹性モードピーク周波数近傍 の場合は, $\hat{G}_{P}{ }^{-1}(s)$ には弾性モードピークが考慮されていないことから， $\hat{G}_{P}{ }^{-1}(s) G_{P}(s)$ は非常に大きなゲインを 持つ. したがって, 式（13）からこの周波数領域にて $F(s) \approx 1$ となるようなフィルタを用いた場合には，推定外 乱 $\hat{d}_{x}$ は制御入力 $F_{x}$ 及び外乱入力 $\bar{d}_{x}$ のモードピーク成分を増幅したような信号となる. これは推定外乱 $\hat{d}_{x}$ をフ ィードバックした場合に外乱オブザーバによって弾性モードを励起する可能性があることを示唆しており，系の 安定性という観点では望ましくない，そこで，弾性モードの励起を避けるためのフィルタの設計指標として $F(s) \hat{G}_{P}{ }^{-1}(s) G_{P}(s)$ のゲインを評価することを提案する. まず, 式 (13) から $F(s) \hat{G}_{P}{ }^{-1}(s) G_{P}(s)$ のゲインが小さい 場合には外乱入力 $\bar{d}_{x}$ の弾性モードピーク成分が増幅されないことがわかる.さらに， $\hat{G}_{P}^{-1}(s) G_{P}(s)$ が弾性モー ドピーク位置にて高いゲインを持つであろうことから, $F(s) \hat{G}_{P}{ }^{-1}(s) G_{P}(s)$ のゲインが十分に小さい場合には $F(s)$ 及び $F(s)\left\{\hat{G}_{P}{ }^{-1}(s) G_{P}(s)-1\right\}$ のゲインも非常に小さく, 制御入力 $F_{x}$ の弾性モードピークも同様に増幅されな いことがわかる．以上のことから外乱オブザーバのフィルタ $F(s)$ の設計の際には以下の点を留意する必要があ る. 
（a）外乱オブザーバ全体がプロパーとなる次数である必要がある.

（b）外乱の推定・相殺性能の向上のため制御帯域では $F(s) \approx 1$ という特性が望ましい.

(c) 推定外乱 $\hat{d}_{x}$ のフィードバックによる弾性モードの励起を防ぐために, 弾性モードピーク位置付近では $F(s) \hat{G}_{P}{ }^{-1}(s) G_{P}(s)$ のゲインが十分に小さくなるような特性が望ましい.

上記の要件を満たすフィルタ $F(s)$ として，式（14）に示すようなローパスフィルタとノッチフィルタを組み合 わせたものを用いることとする.

$$
F(s)=\left(\frac{\omega_{c_{-} D O}}{s+\omega_{c_{-} D O}}\right)^{2} \prod_{i=1}^{2}\left(H_{0 i} \frac{s^{2}+\left(\omega_{n i} / Q_{n i}\right) s+\omega_{n i}{ }^{2}}{s^{2}+\left(\omega_{d i} / Q_{d i}\right) s+{\omega_{d i}}^{2}}\right)
$$

ローパスフィルタは外乱オブザーバ全体の特性をプロパーにするために, ノッチフィルタは弾性モードピーク近 傍でのフィルタゲインを下げるために用いられる.

また，外乱オブザーバの出力である推定外乱 $\hat{d}_{x}$ を外力推定に用いることを考える．しかしながら，式（12） に示すように, フィルタや, 逆モデルのモデル化誤差の影響により推定外乱 $\hat{d}_{x}$ は外乱入力 $\bar{d}_{x}$ と必ずしも一致 しない. また一方で, 外乱入力 $\bar{d}_{x}$ と実際の外力 $d_{x}$ の間には先述の通り $\bar{d}_{x}=d_{x} / B_{0}$ の関係が存在する. そこで 本論文ではまず, 式 (12) の $H_{d}(s)$ を実験的に同定し, その逆をオフラインにて推定外力の時刻歴データにか けることにより推定外乱 $\hat{d}_{x}$ から外乱入力 $\bar{d}_{x}$ を復元し, さらにパラメータから $B_{0}$ を用いて外乱入力 $\bar{d}_{x}$ から実 際の外力 $d_{x}$ を推定寸ることを考える. この処理を式にて示すと以下のようになる. なお， パラメータから $B_{0}$ は実験的に同定した制御対象の剛体モードモデル $G_{P R}$ のパラメータから算出される.

$$
D_{x}=B_{0} \bar{D}_{x}=B_{0} H_{d}^{-1}(s) \hat{D}_{x}
$$

\section{$3 \cdot 4$ フィードフォワードコントローラ}

本実験装置において回転軸に対して任意軌道の生成と追従を実現するため, 図 3 に示すように制御対象の逆モ デルに基づくフィードフォワードコントローラを用いる (Araki and Taguchi, 2003). 逆モデル $\hat{G}_{P}^{-1}(s)$ は逆モデル 型外乱オブザーバと同様に実験的に同定した制御対象の剛体モードモデル $G_{P R}(s)$ の逆を用いる. 目標モデル $G_{D}(s)$ はフィードフォワードコントローラの特性をプロパーにするために以下に示寸 2 次のローパスフィルタ を用いる.

$$
G_{D}(s)=\left(\frac{\omega_{c_{-} F F}}{s+\omega_{c_{-} F F}}\right)^{2}
$$

このフィードフォワードコントローラにより，回転軸の任意軌道を実現するための指令值を生成する.

\section{4. 実験}

\section{$4 \cdot 1$ 実験装置}

本論文にて対象とした実験機の写真を図 6 に示す．実験機は鉛直型の構造を持ち，上端を玉軸受，下端を AMB にて支持されている. AMB は8 極型のものを使用している. 回転軸の上端はユニバーサルジョイント及 びベルトを介して回転軸に回転力を与えるモータと接続されている．位置センサから得られた回転軸の位置情報 は, 制御則を書き込んだ DSP に入力され, 計算した結果が DSP から出力される. DSP の出力はサーボドライバ によって増幅され, サーボドライバから各電磁石に電流が流れ, 回転軸の運動を制御する. また, 光学式の口 ータリーエンコーダを用いて自転速度の計測を行っており，ロータリーエンコーダより回転軸が 1 回転するごと に回転パルスが 1 つ出力されるようになっている. 

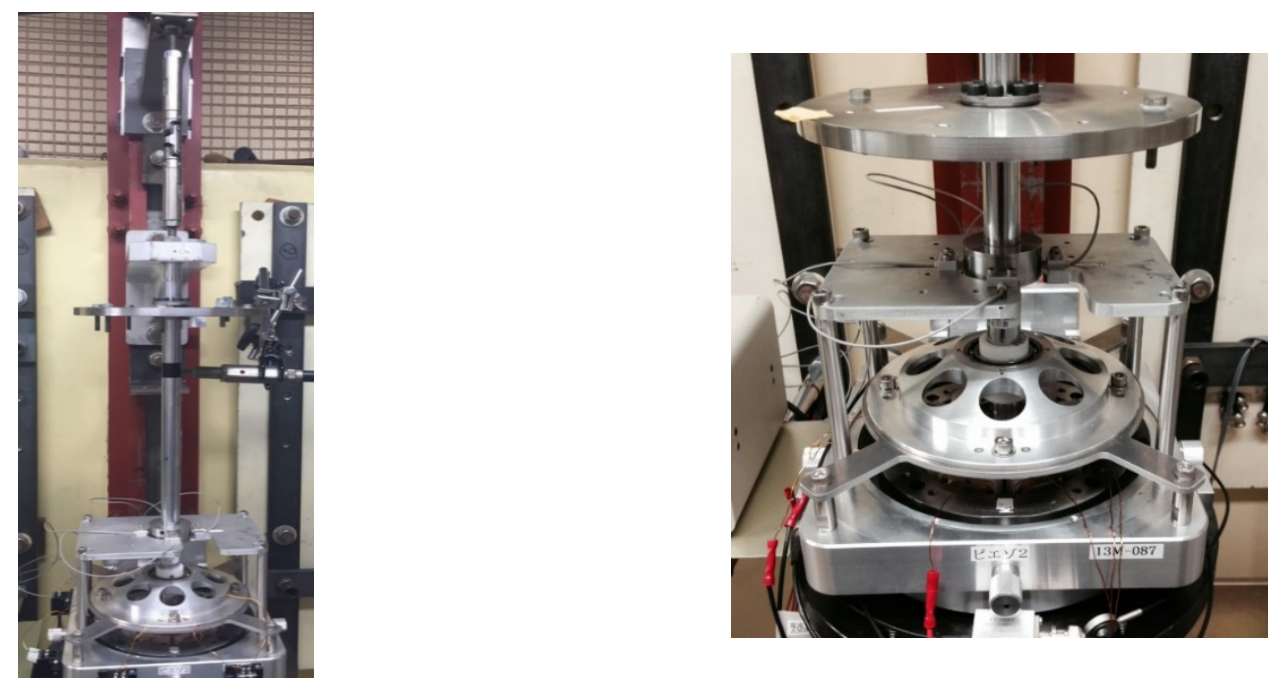

Fig. 6 Experimental Setup

\section{$4 \cdot 2$ 制御対象 $G_{P}(s)$ のシステム同定}

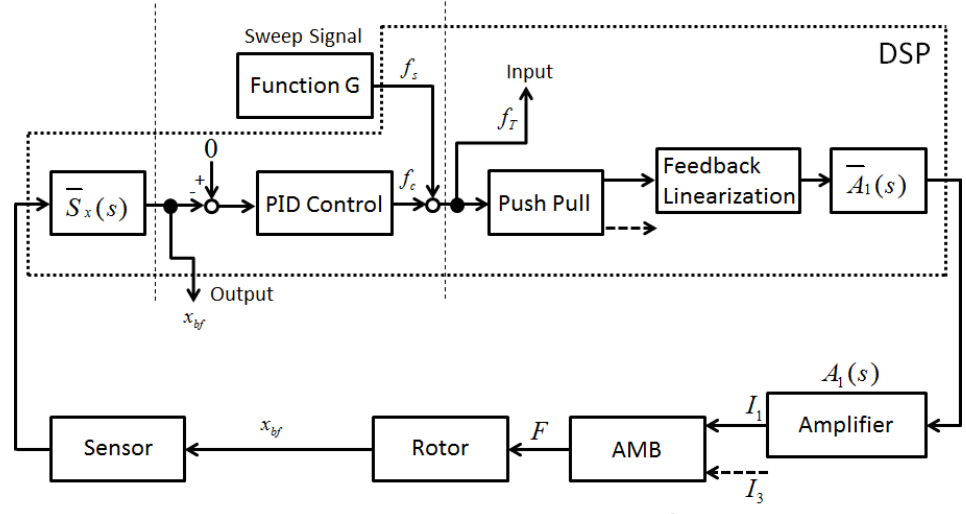

Plant

Fig. 7 Block diagram for closed-loop identification with feedback linearization

まず， AMB とロータ系及びフィードバック線形化コントローラを含む制御対象 $G_{P}(s)$ のモデルを同定した. $G_{P}(s)$ は非制御時は不安定であるため，安定化コントローラにより系を安定化させ，そのときに得られたコント ローラ出力と回転軸の位置信号についての周波数応答比から $G_{P}(s)$ を同定した. 図 7 に同定実験時の $\mathrm{AMB・ \square ー}$ タ系のブロック線図を示す. 目標制御力 $f_{c}$ を制御対象の入力, センサ定数により修正したのちの位置センサの出 力を制御対象の出力とみなした. $G_{P}(s)$ の周波数特性を図 8 に示す. この周波数応答に対し，フィードフォワー ドコントローラおよび逆モデル型外乱オブザーバの設計に必要な, 制御対象の剛体モードモデル $G_{P R}(s)$ をカー ブフィッティングにより同定した。 そのモデルを式（17）に，そして各パラメータの数值を表 1 に示す.

$$
G_{P R}(s)=\frac{b_{0}}{s^{2}+a_{1} s+a_{0}}
$$

Table 1 Parameters of identified control object $G_{P R}(s)$ : For equation (17)

\begin{tabular}{c|c|c|c}
\hline \hline Axis & $a_{0}$ & $a_{1}$ & $b_{0}$ \\
\hline \hline$x$ & $1.5781 \times 10^{3}$ & -23.003 & 0.14909 \\
\hline$y$ & $1.3982 \times 10^{3}$ & -20.050 & 0.13387 \\
\hline \hline
\end{tabular}



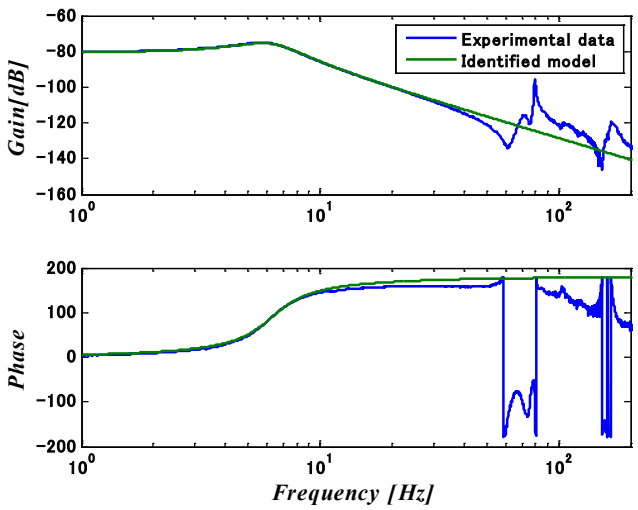

(a) $\mathrm{x}$-axis
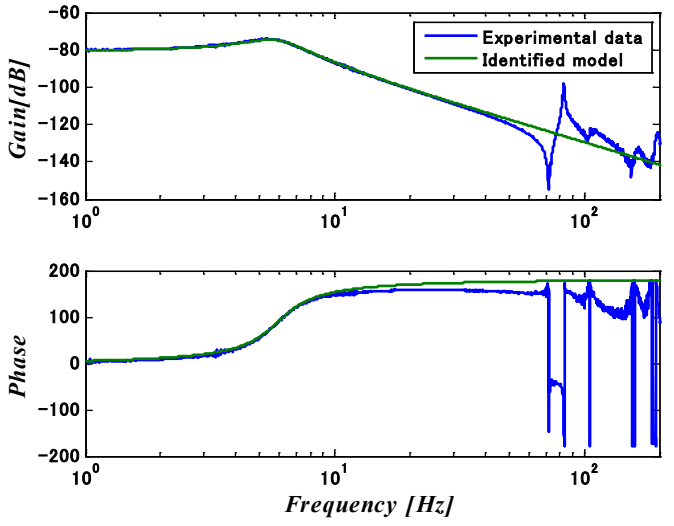

(b) y-axis

Fig. 8 In frequency domain, the experimental data of the plant and the identified rigid body mode are plotted with the blue solid line and green solid line. There are two resonance peaks caused by the elastic modes. The identified model for designing the feed-forward controller and observer almost coincides the experimental data under $20 \mathrm{~Hz}$.

まず，実験により得られた周波数応答に関して $x, y$ 方向共に $80 \mathrm{~Hz}, 160 \mathrm{~Hz}$ 付近に弾性モードによるピークが存 在していることが確認できる.さらに，そのピークの形状から $x, y$ 方向の間で異方性がみられる. これは電磁 石の特性のばらつきによるものだと考えられる.また， $7 \mathrm{~Hz}$ 付近で位相が進むような特性については，玉軸受 支持点の摩擦やフィードバック線形化時のモデル化誤差などが要因として考えられ，(電気学会編，1993，日本 機械学会編，1995，井上他，2005)，原因の究明まで至っていないが，本実験装置作成にあたっては，コントロ 一ラ設計に必要なモデルが得られればよいため，原因が究明できないことについて特に問題はない．式（17）の モデルを用いたフィッティング結果については, 剛体モードの特性が支配的である $17 \mathrm{~Hz}$ 以下で $x, y$ 方向共に 良好にフィッティングできていることが確認できる．また，式（9）と式（17）の分母の係数の比較により，フ イッティングにより得られた $b_{0}$ を用いて $B_{0}$ は以下のように算出した.

$$
B_{0}=\left(l_{a}^{2} / I\right) b_{0}
$$

\section{$4 \cdot 3$ フィードパックコントローラ $K_{F B}(s)$ の設計}

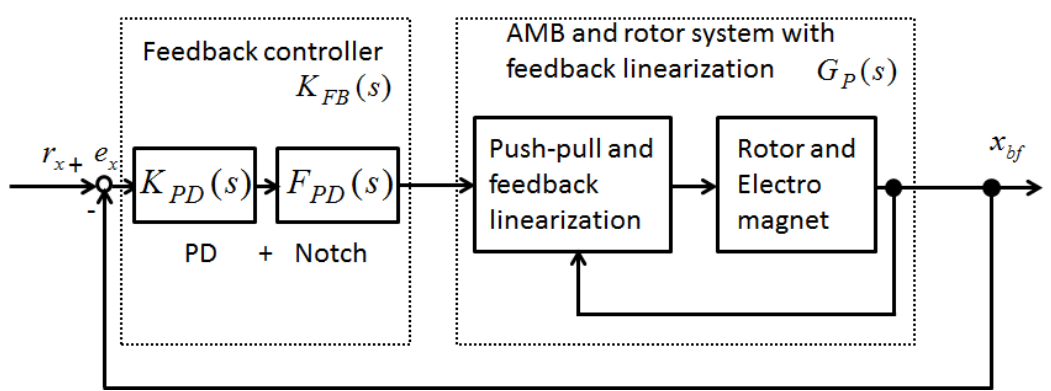

Fig. 9 Block diagram of AMB control system for stabilization

図 9 に示す閉ループ系に対し，フィードバックコントローラの設計を行った. 先述の通り，フィードバックコ ントローラはPD コントローラとノッチフィルタを組み合わせたものを用いた. 閉ループ系の極が重根，かつ制 御帯域が $17 \mathrm{~Hz}$ となるように極配置で設計した PD ゲインを表 2 に示す.

Table 2 Parameters of PD controller: For equation (11)

\begin{tabular}{c|c|c|c}
\hline \hline Axis & $k_{P}$ & $k_{D}$ & $\omega_{c_{-} P D}$ \\
\hline \hline$x$ & 1710.9 & 737.8 & 300 \\
\hline$y$ & 3258.6 & 800.3 & 300 \\
\hline \hline
\end{tabular}


Table 3 Parameters of notch filter in feedback controller: For equation (11)

\begin{tabular}{c|c|c|c|c}
\hline \hline \multirow{2}{*}{} & \multicolumn{2}{|c|}{$x$-axis } & \multicolumn{2}{c}{$y$-axis } \\
\cline { 2 - 5 } & 1 st peak & 2nd peak & 1st peak & 1 \\
\hline \hline$H_{0}$ & 0.739 & 1 & 0.900 & $170 \times 2 \pi$ \\
\hline$\omega_{n}$ & $79 \times 2 \pi$ & $165 \times 2 \pi$ & $82 \times 2 \pi$ & $170 \times 2 \pi$ \\
\hline$\omega_{d}$ & $62 \times 2 \pi$ & $165 \times 2 \pi$ & $71 \times 2 \pi$ & 0 \\
\hline $1 / Q_{n}$ & $1 / 33.52$ & 0 & $1 / 86.82$ & $1 / 2$ \\
\hline $1 / Q_{d}$ & $1 / 4$ & $1 / 4$ & $1 / 10$ & \\
\hline \hline
\end{tabular}

ループ整形により設計したノッチフィルタのパラメータを表 3 に示す. 図 10 にオープンループ伝達関数の周波 数特性の比較を示す. $80 \mathrm{~Hz}, 160 \mathrm{~Hz}$ 付近に存在する制御対象の弾性モードピークに対してノッチフィルタを一 つずつ配置することにより，各ピークに対する安定余裕が増大していることがわかる．また，80 Hz側のノッチ フィルタを左右非対称に設計することにより，17 Hz 以下の制御帯域においてのコントローラのゲインを増大さ せていることがわかる。
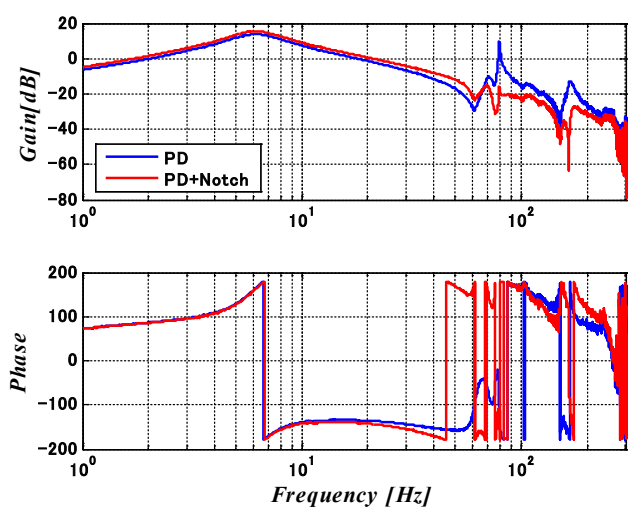

(a) $x$-axis
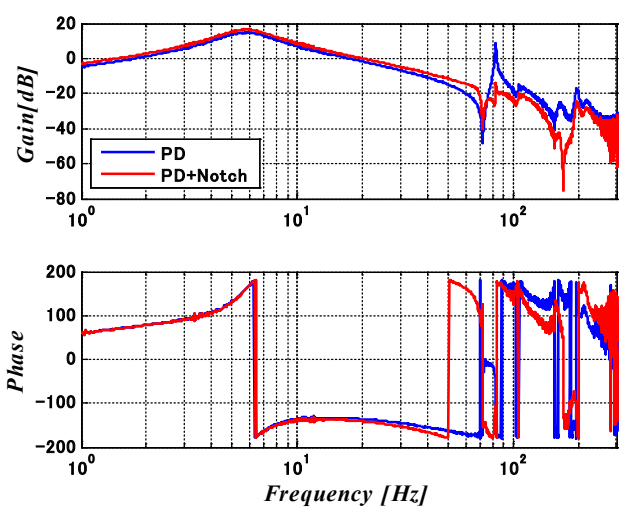

(b) y-axis

Fig. 10 The frequency response of the open loop with only PD controller and with PD controller and notch filters are plotted with the blue solid line and red solid line. The two resonances peaks can be compensated by the notch filters. The gain under $20 \mathrm{~Hz}$ is increased by the notch filters which has asymmetry gain characteristics. It leads improvement of the performance and stability.

困 11 に感度関数の周波数特性の比較を示す.ノッチフィルタを用いることにより，80 Hz，160 Hz 付近の弾性 モードのゲインが低減していることから，ループ整形により安定性が向上していることが確認できる.
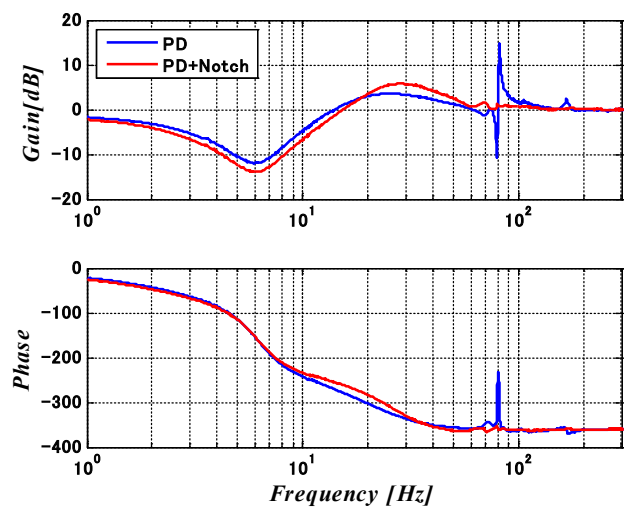

(a) $\mathrm{x}$-axis
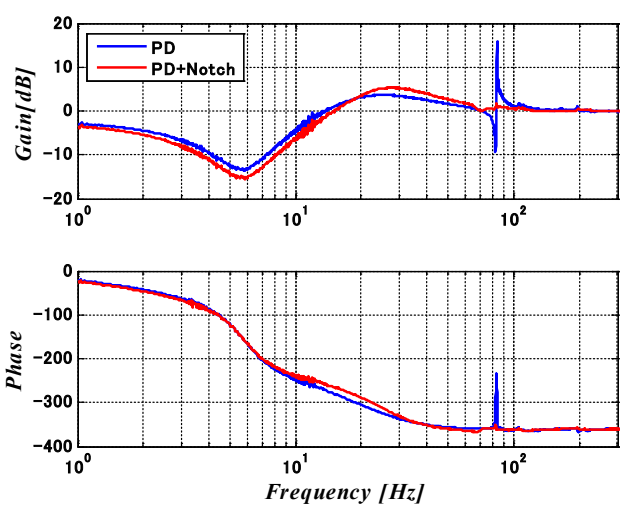

(b) y-axis

Fig. 11 The frequency response of the sensitivity function with only PD controller and with PD controller and notch filters are plotted with blue solid line and red solid line. The peaks at 80 and $160 \mathrm{~Hz}$ caused by the elastic modes are compensated by the notch filters. 


\section{$4 \cdot 4$ 逆モデル型外乱オブザーバのフィルタ $F(s)$ の設計}

フィルタ $F(s)$ はローパスフィルタとノッチフィルタを組み合わせたものを用いた．ローパスフィルタは $17 \mathrm{~Hz}$ 以下の制御帯域にて $F(s) \approx 1$ となるようにカットオフ周波数は $1000 \mathrm{rad} / \mathrm{s}$ に設定した. ノッチフィルタは $80 \mathrm{~Hz}$, $160 \mathrm{~Hz}$ 付近に存在する制御対象の弾性モードピークに対して 1 つずつ配置し, 弾性モードピーク近傍で $F(s) \hat{G}_{P}{ }^{-1}(s) G_{P}(s)$ のゲインが-20 dB 以下となるように設定した。その設計結果を表 4 に示す. 図 12 は $\hat{G}_{P}(s)=G_{P R}(s)$ と $F(s) G_{P}(s)$ のボード線図の比較を示したものである. 図中の $F(s) G_{P}(s)$ のゲインから $\hat{G}_{P}(s)$ の ゲインを引いたものが $F(s) \hat{G}_{P}{ }^{-1}(s) G_{P}(s)$ のゲインと対応している. 図より, 弾性モードピーク近傍にて設定した 条件が満たされていることがわかる.
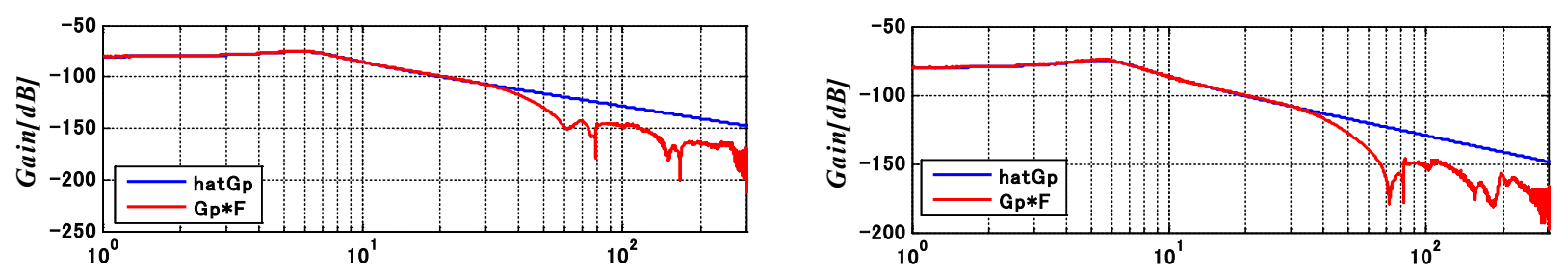

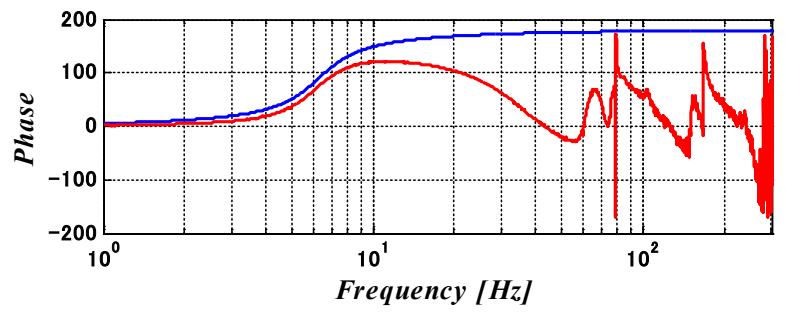

(a) $\mathrm{x}$-axis

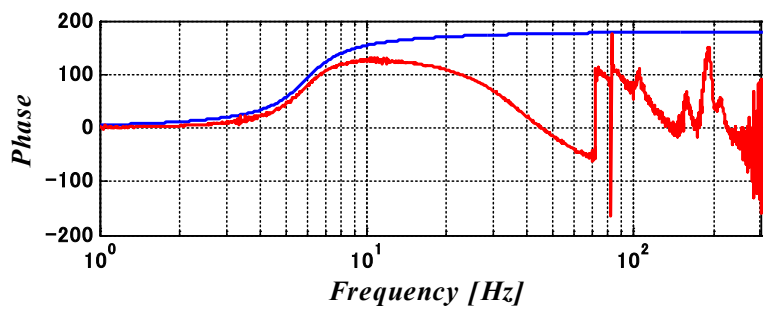

(b) y-axis

Fig. 12 The frequency response of $\hat{G}_{P}(s)$ and $F(s) G_{P}(s)$ are plotted with blue solid line and red solid line. To improve the stability, the gain of frequency response upper $20 \mathrm{~Hz}$ was decreased by $F(s)$

Table 4 Parameters of notch filter in inversion based disturbance observer: For equation (14)

\begin{tabular}{c|c|c|c|c}
\hline \hline \multirow{2}{*}{} & \multicolumn{2}{|c|}{$x$-axis } & \multicolumn{2}{c}{$y$-axis } \\
\cline { 2 - 5 } & 1 st peak & 2nd peak & 1st peak & 2nd peak \\
\hline \hline$H_{0}$ & 0.208 & 0.976 & 0.208 & 0.976 \\
\hline$\omega_{n}$ & $79 \times 2 \pi$ & $167 \times 2 \pi$ & $79 \times 2 \pi$ & $167 \times 2 \pi$ \\
\hline$\omega_{d}$ & $36 \times 2 \pi$ & $165 \times 2 \pi$ & $36 \times 2 \pi$ & $165 \times 2 \pi$ \\
\hline $1 / Q_{n}$ & 0 & 0 & 0 & $1 / 1.2$ \\
\hline $1 / Q_{d}$ & $1 / 1.2$ & $1 / 1.2$ & $1 / 1.2$ & 0 \\
\hline \hline
\end{tabular}

\section{$4 \cdot 5$ 軌道追従精度の検証実験}

設計したフィードフォワードコントローラによる指令值の生成と，フィードバックコントローラによる軌道追 従制御の精度を検証する実験を行った。 まず，回転軸が無回転の状態で，周波数 780rpm（振れ回り角周波数 $\Omega$ $=13 \times 2 \pi \mathrm{rad} / \mathrm{s})$ にて, 半径 $0.2 \mathrm{~mm}$ の円軌道となるようにフィードフォワードコントローラから指令值を生成し, その軌道に追従する実験を行った。 なお，フィードフォワードコントローラのカットオフ周波数 $\omega_{c_{-} F F}$ は 700 $\mathrm{rad} / \mathrm{s}$ とした. 縦軸にその際の入力振幅と応答振幅の比を, 横軸に入力周波数を取ったものを図 13 に示す. なお 入力振幅と応答振幅は $x, y$ 方向それぞれの入力と応答 $r_{x}, r_{y}, x_{b f}, y_{b f}$ の時刻歴データから, FFT を用いて入力 周波数近傍のみを取り出した信号の振幅を計算し，その比を取ることにより算出している．また，図中の青い線 は $x, y$ 方向の平均值を表している. この図から, 特に $1 \sim 17 \mathrm{~Hz}$ の範囲では振幅誤差 $5 \%$ 未満となっていること から，設計した制御系が良好な目標值追従性能を発揮できていることがわかる．また $x, y$ 方向の振幅がほぼ一 
致していることから，もともと $x, y$ 方向に関して制御対象が持っていた異方性が制御により十分補償されてい ることがわかる. 図 14 には入力周波数 $13 \mathrm{~Hz}$ の場合の目標軌道と回転軸軌道の比較を示す。この図からも高い 精度で軌道追従制御が行えていることが確認できる.

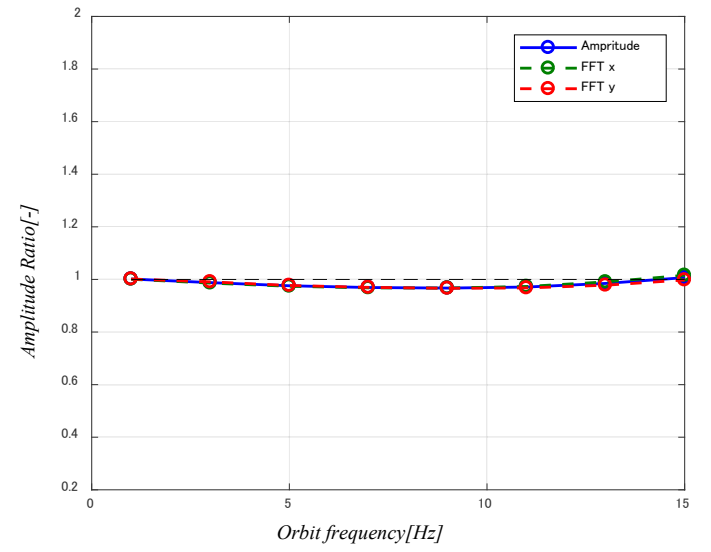

Fig. 13 The amplitude ratio between target and actual position were calculated. The target ratio, the ratio for $x$-direction and $y$-direction are plotted with black broken line, blue solid line with circle marks and red solid line with circle marks. For both direction, the ratios were almost same as the target ratio.

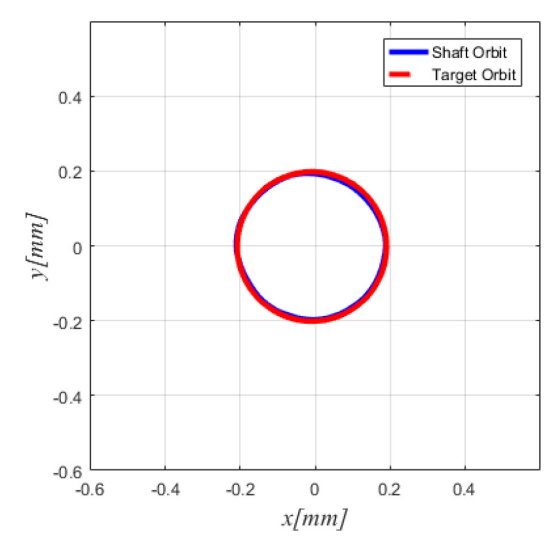

Fig. 14 The orbits of the rotational shaft which whirls at $\Omega=13 \times 2 \pi \mathrm{rad} / \mathrm{s}$ (no rotation) was verified. The target orbit and the actual orbit are plotted with blue solid line and red solid line. The actual orbit was almost same as the target.

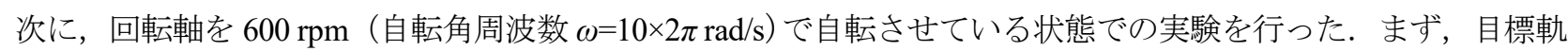
道を与えないときの回転軸の軌道を図 15 に示寸. $x, y$ 方向ともに周波数 $10 \mathrm{~Hz}$ にて振幅 $0.02 \mathrm{~mm}$ 程度で振動し ていることが確認された．これは，センサ部のランナウトの影響だと考えられる．さらに，回転軸を自転させな がら，回転軸の軌道が周波数 780rpm（振れ回り角周波数 $\Omega=13 \times 2 \pi \mathrm{rad} / \mathrm{s}$ ）にて $x$ 方向の振幅を $0.2 \mathrm{~mm}, y$ 方向の 振幅を $0.15 \mathrm{~mm}$ の楕円軌道となるようにフィードフォワードコントローラにより指令值を生成し, 軌道追従実験 を行った．実際の回転機械では不釣り合い力の異方性や重力の影響により棈円軌道になり得ることが想定され る. その結果を図 16 に示寸，これらの結果から自転状態であっても高い精度で回転軸の軌道追従制御を実現で きていることが確認できる.
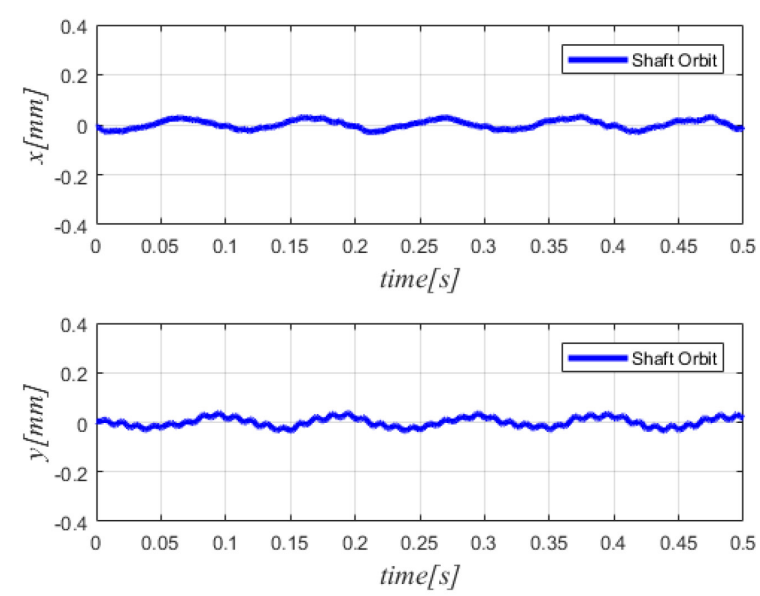

(a) Time history

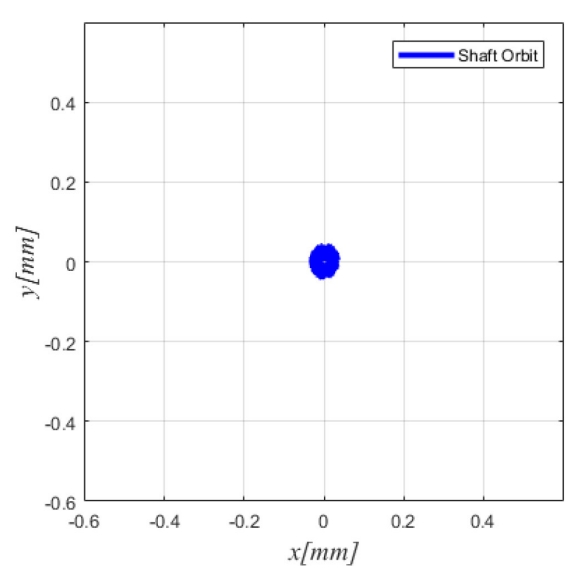

(b) orbit

Fig. 15 The orbit of the rotational shaft which whirls at $\omega=10 \times 2 \pi \mathrm{rad} / \mathrm{s}$ (no whirling) was verified. The actual orbit is plotted with blue solid line. In both directions, there were vibrations whose amplitude about $0.02 \mathrm{~mm}$ at $10 \mathrm{~Hz}$. The vibration may be caused by sensor runout. 

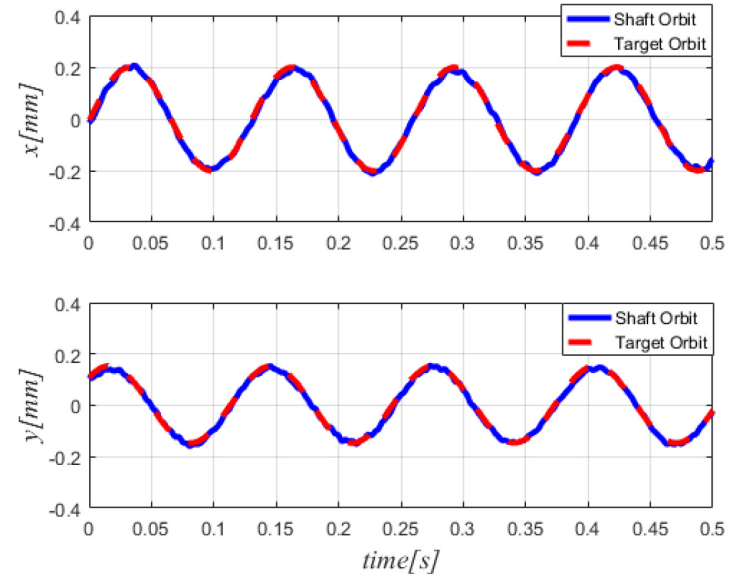

(c) Time history

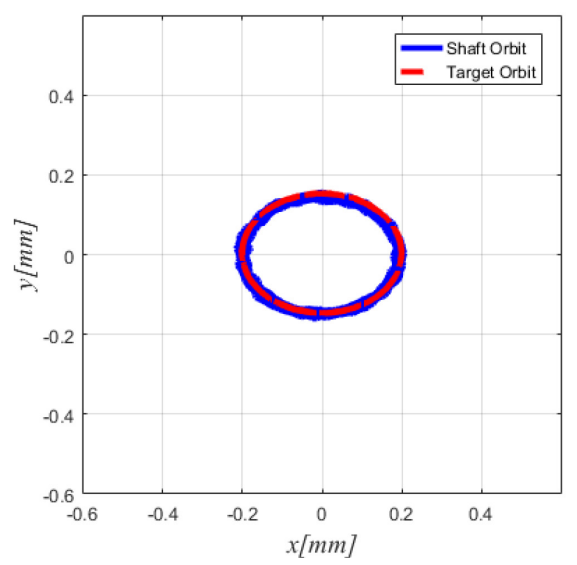

(d) orbit

Fig. 16 The orbits of the rotational shaft which whirled at $\Omega=13 \times 2 \pi \mathrm{rad} / \mathrm{s}$ and rotated at $\omega=10 \times 2 \pi \mathrm{rad} / \mathrm{s}$ was verified. The target orbit and the actual orbit are plotted with red broken line and blue solid line. The actual orbit was almost same as the target. It means that the designed control system achieved high precision tracking control.

\section{$4 \cdot 6$ 外力推定精度の検証実験}

\section{$4 \cdot 6 \cdot 1$ ロードセルを用いた準静的な外カに対する検証}

設計した外乱オブザーバによる外力推定精度を検証する実験を行った．まず，準静的な外力に対する検証とし て, ロードセルを用いた外力推定の実験を行った。図 17 に示すように回転軸の玉軸受の支持点から $l_{\text {load }}$ の距離 に接触するようにロードセルを設置し，回転軸に対しての押し付け度合いを変化させた．そしてその際のロード セルの出力する力の計測值と, 式（15）に示寸提案する推定法を用いて得られる推定值とを比較した.

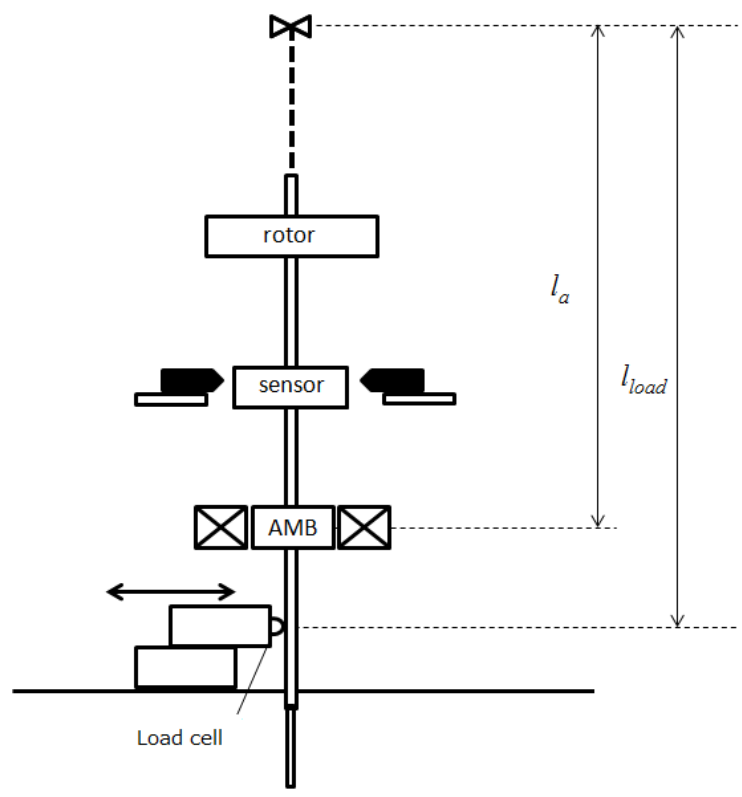

Fig. 17 Position of setting load cell

$H_{d}(s)$ はオブザーバの設計に用いたモデルと実際のモデルの差分となる. 本実験では, 入力した外乱と推定し た外乱との周波数応答比がそれに相当する. そこで, DSP の制御信号に外力 $d(x)$ とてスイープ信号を加え，そ のときの外乱オブザーバの出力 $d(x)$ の取得し, その周波数応答比を $H_{d}(s)$ として同定した. その周波数応答を図 18 に示寸，本実験の動作範囲である $20 \mathrm{~Hz}$ 以下ではゲイン特性がほぼ 1 であるが，位相特性は遅れが見られる. 
この位相遅れは，主に DSP から AMB 間に存在する信号伝達のむだ時間が要因と考えられる． $H_{d}(s)$ のモデル を式（19）に示す.

$$
H_{d}(s)=\frac{b_{h 3} s^{3}+b_{h 2} s^{2}+b_{h 1} s+b_{h 0}}{s^{4}+a_{h 3} s^{3}+a_{h 2} s^{2}+a_{h 1} s+a_{h 0}}
$$

また同定した $H_{d}(s)$ のパラメータと $B_{0}$ の值を以下の表 5 に示す，そして，図 19 にロードセルの計測值と提案 手法による外力推定值の時刻歴の比較を示す．ロードセルの測定值と外力推定值が定量的に一致していることか ら提案する外力推定法が有効であることが確認できる.
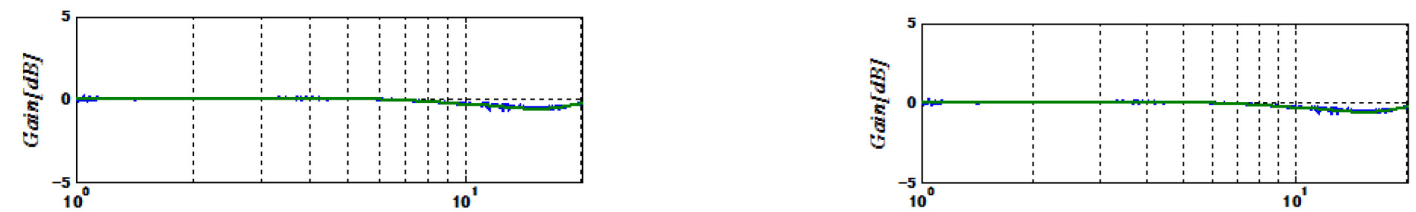

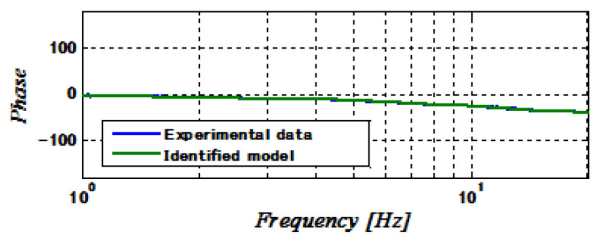

(a) $\mathrm{x}$-axis

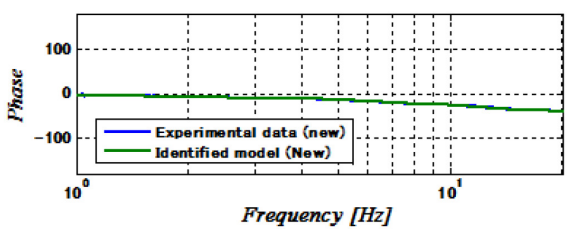

(b) y-axis

Fig. 18 Comparison of frequency responses between input disturbance and estimated disturbance

Table 5 Parameters for estimating disturbance forces: For equation (18) and (19)

\begin{tabular}{c|c|c|c|c|c|c|c|c|c}
\hline \hline Axis & $a_{h 0}$ & $a_{h 1}$ & $a_{h 2}$ & $a_{h 3}$ & $b_{h 0}$ & $b_{h 1}$ & $b_{h 2}$ & $b_{h 3}$ & $B_{0}$ \\
\hline \hline$x$ & $552 \times 10^{6}$ & $101 \times 10^{5}$ & $820 \times 10^{2}$ & 232 & $557 \times 10^{6}$ & $618 \times 10^{4}$ & $264 \times 10^{2}$ & -69.4 & 0.570 \\
\hline$y$ & $-598 \times 10^{6}$ & $484 \times 10^{-3}$ & $530 \times 10^{2}$ & 54.7 & $-599 \times 10^{6}$ & $448 \times 10^{4}$ & $266 \times 10^{2}$ & -26.5 & 0.533 \\
\hline \hline
\end{tabular}

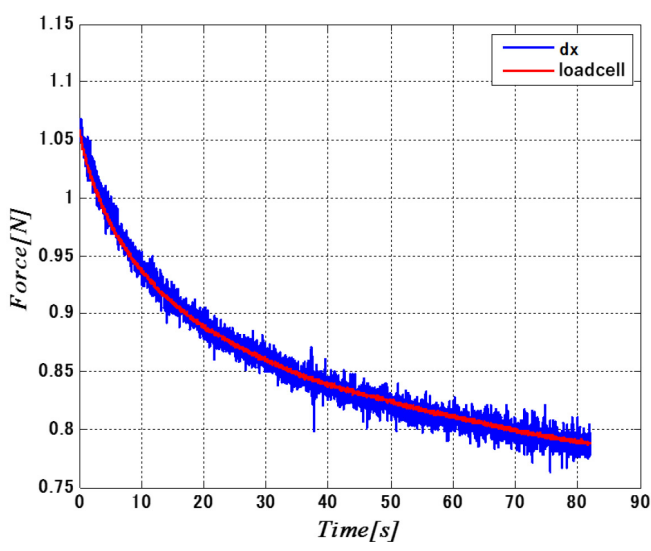

(a) $x$-axis

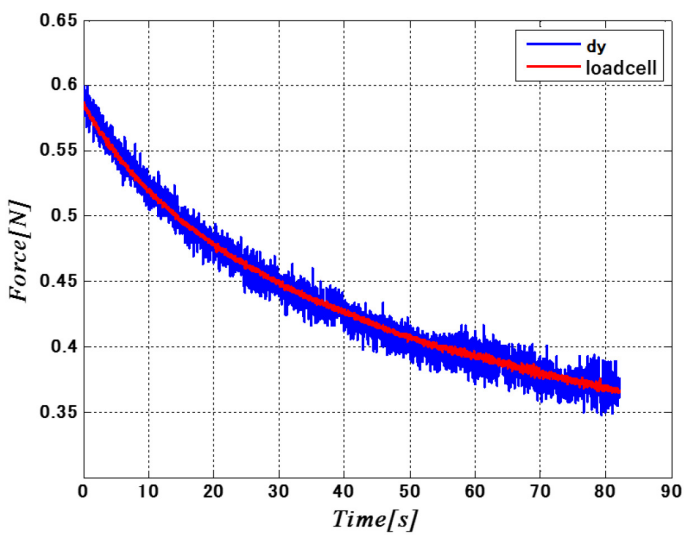

(b) y-axis

Fig. 19 The time responses of the load cell and the estimated external force are plotted with red solid line and blue solid line. The time response of estimated external force was almost same as that of the load cell. 


\section{4・6・2 サインスイープ信号による動的な外力に対する検証}

次に動的な外力に対する検証を行うため, 疑似外力として DSP からサインスイープ信号を出力し, そのとき の外乱オブザーバの出力と比較した．その結果を図 20 に示す.今回の実験の動作範囲である 3 20Hzのサイン スイープ信号を 45 秒間入力した．なお，推定した信号については前述のむだ時間を補正している．図 20 から両 者の時間応答はほぼ一致していることが分かる.

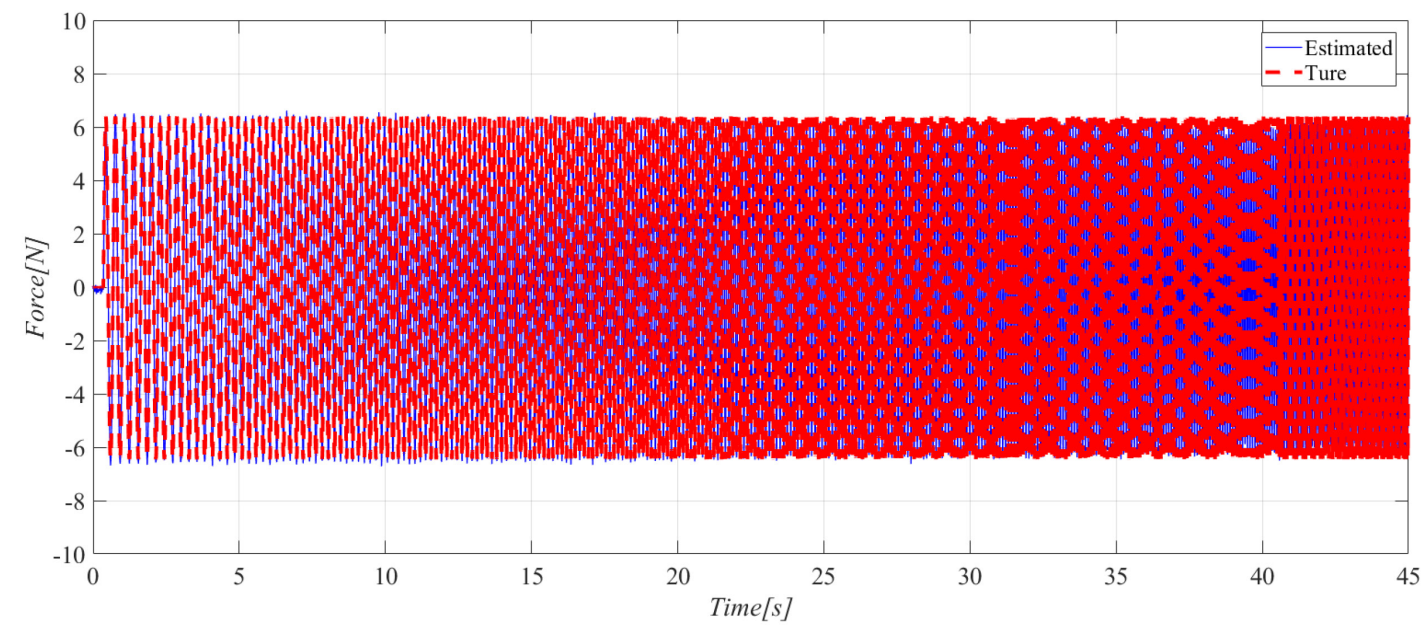

(a) $0 \sim 45 \mathrm{sec}: 3 \sim 20 \mathrm{~Hz}$

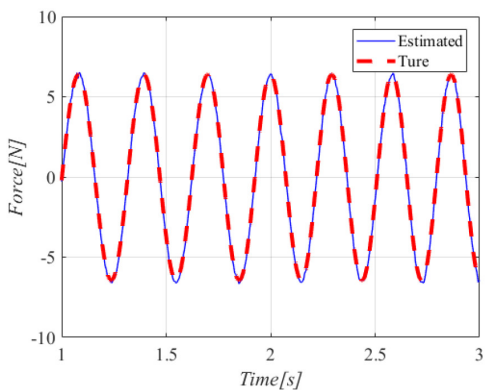

(b) $1 \sim 3 \mathrm{sec}$ : around $3 \mathrm{~Hz}$

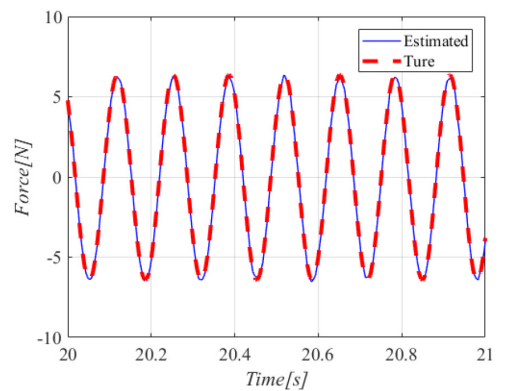

(c) $20 \sim 21 \mathrm{sec}$ : around $10 \mathrm{~Hz}$

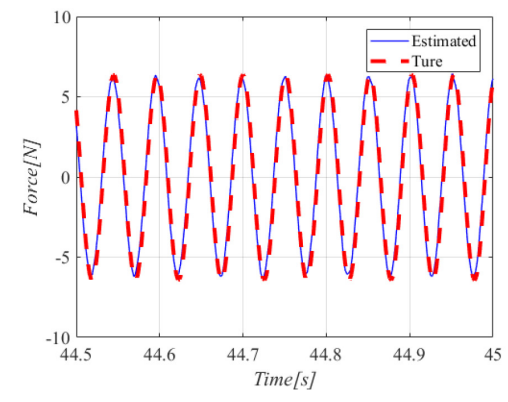

(d) $44.5 \sim 45 \mathrm{sec}$ : around $20 \mathrm{~Hz}$

Fig. 20 The time responses of the fictitious external forces (true) and the estimated external force are plotted with red broken line and blue solid line. The time response of estimated external force was almost same as that of the load cell. It means that the designed controller can estimate the external force accurately.

\section{7 任意軌道に対する追従制御と外力推定の実験}

本実験装置の目的は，回転軸を任意の振れ回り軌道に追従させ，その上でロータ系に作用する外力を推定する ことである。そこで，開発した実験装置の妥当性を確認するため，任意軌道に対する追従制御と，外力推定を同 時に実施する実験を行った。本実験において，目標とした回転軸の振れ回り軌道は，周波数が 462rpm（振れ回 り角周波数 $\Omega=7.7 \times 2 \pi \mathrm{rad} / \mathrm{s} ）$ で振幅が $0.2 \mathrm{~mm}$ で円軌道となるように，フィードフォワードコントローラから指 令值を生成した，振幅については回転軸が大振幅で振れ回る状態で外力を推定できることを確認するため，クリ アランス $0.4 \mathrm{~mm}$ の $50 \%$ とした。 この指令值にフィードバックコントローラと外乱オブザーバにより回転軸を高 精度に追従させ，併せて外乱オブザーバの出力から外力を推定した. 本実験で推定する外力は，図 21 に示すよ うにロータ系のバランシング平面に対して既知のおもりを付加して故意に生じさせた不釣り合い振動とした.

まず，フィードフォワードコントローラにより生成した円軌道に対する軌道追従の結果を図 22 に示す。この とき，回転軸は $600 \mathrm{rpm}(\omega=10 \times 2 \pi \mathrm{rad} / \mathrm{s})$ で自転させている状態とした．比較のため，外乱才ブザーバを用いない ときの結果も示している．外乱オブザーバを用いることで外乱を補償でき，目標軌道に対する追従精度が向上し ていることが分かる。このとき，目標軌道に対する誤差の標準偏差は約 $0.01 \mathrm{~mm}$ であり，サブマイクロメートル 
オーダーの精度で追従制御できることが確認された．なお，残存している誤差の主要因はセンサ部のランナウト だと考えられる.

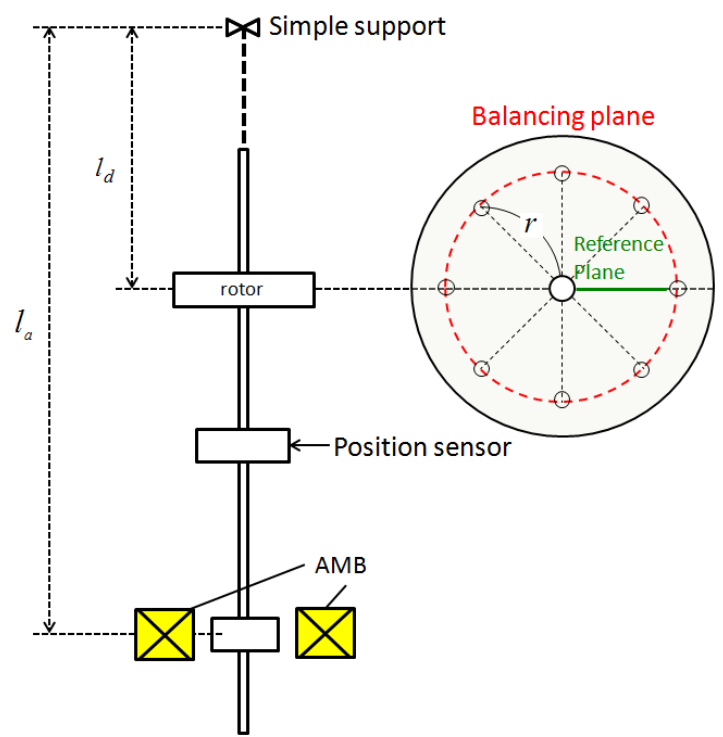

Fig. 21 Geometrical relation of AMB and balancing plane

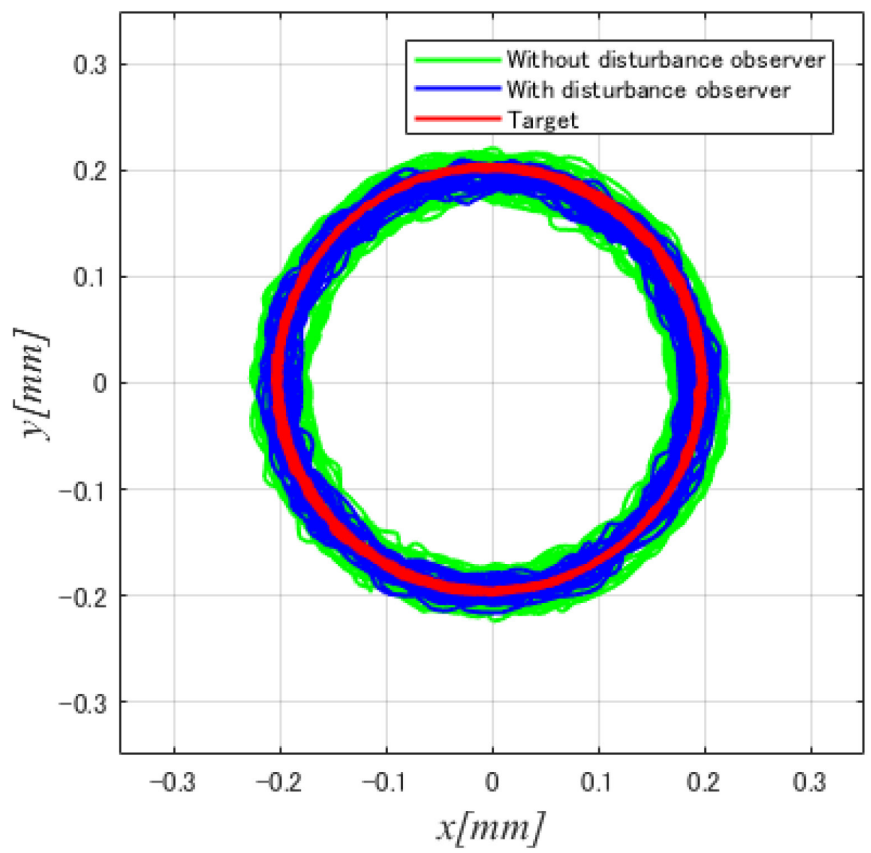

Fig. 22 The orbits of the rotational shaft which whirled at $\Omega=7.7 \times 2 \pi \mathrm{rad} / \mathrm{s}$ and rotated at $\omega=10 \times 2 \pi$ $\mathrm{rad} / \mathrm{s}$ was verified. The target orbit and the actual orbit with disturbance observer case are plotted with red solid line and blue solid line. Moreover, the actual orbit without disturbance observer case is plotted green solid line. The actual orbit with disturbance observer case was almost same as the target. It means that the experimental system achieved precision tracking control and disturbance estimation. 
さらに, FFT を用いて自転速度成分のみを抽出した外乱オブザーバの出力 $\hat{d}_{x \omega}, \hat{d}_{y \omega}$ において外力推定を行っ た.まず， $\hat{d}_{x \omega}, \hat{d}_{y \omega}$ は式（20）のように書き表すことができる.

$$
\begin{aligned}
& \hat{d}_{x \omega}=\hat{F}_{\omega} \cos \left(\omega t+\phi_{f \omega}\right)=U \omega^{2} \cos \left(\omega t+\phi_{u}\right)+T \cos \left(\omega t+\phi_{T}\right) \\
& \hat{d}_{y \omega}=\hat{F}_{\omega} \sin \left(\omega t+\phi_{f \omega}\right)=U \omega^{2} \sin \left(\omega t+\phi_{u}\right)+T \sin \left(\omega t+\phi_{T}\right)
\end{aligned}
$$

ここで， $\hat{F}_{\omega} ， \phi_{f \omega}$ は外乱オブザーバの出力における自転速度成分の振幅と位相， $U, \phi_{u}$ は本実験で推定の対 象となる不釣り合い力の振幅とその位相，そして， $T, \phi_{T}$ はセンサ部のランナウトなどの外乱の振幅とその位 相である. 本実験では以下の計算を行うことにより，ランナウトなどを排除し，不釣り合い力の推定を行う. 式（20）を $2 つ の$ 自転速度の場合について考えて $t=0$ を代入すると以下の連立方程式を得る.

$$
\begin{aligned}
& \hat{F}_{\omega i} \cos \phi_{f \omega i}=U \omega_{i}^{2} \cos \phi_{u}+T \cos \phi_{T} \\
& \hat{F}_{\omega i} \sin \phi_{f \omega i}=U \omega_{i}{ }^{2} \sin \phi_{u}+T \sin \phi_{T} \\
& \hat{F}_{\omega j} \cos \phi_{f \omega j}=U \omega_{j}{ }^{2} \cos \phi_{u}+T \cos \phi_{T} \\
& \hat{F}_{\omega j} \sin \phi_{f \omega j}=U \omega_{j}{ }^{2} \sin \phi_{u}+T \sin \phi_{T}
\end{aligned}
$$

この連立方程式を解き，次式のように推定した不釣り合い力の振幅 $U$ とその位相 $\phi_{u}$ を得る.

$$
\begin{aligned}
& U=\frac{\sqrt{\left(\hat{F}_{\omega i} \cos \phi_{f \omega i}-\hat{F}_{\omega j} \cos \phi_{f \omega j}\right)^{2}+\left(\hat{F}_{\omega i} \sin \phi_{f \omega i}-\hat{F}_{\omega j} \sin \phi_{f \omega j}\right)^{2}}}{\left(\omega_{i}{ }^{2}-\omega_{j}{ }^{2}\right)} \\
& \phi_{u}=\tan ^{-1}\left(\frac{\hat{F}_{\omega i} \sin \phi_{f \omega i}-\hat{F}_{\omega j} \sin \phi_{f \omega j}}{\hat{F}_{\omega i} \cos \phi_{f \omega i}-\hat{F}_{\omega j} \cos \phi_{f \omega j}}\right)
\end{aligned}
$$

本実験では $700 \mathrm{rpm}(=11.67 \times 2 \pi \mathrm{rad} / \mathrm{s}), 900 \mathrm{rpm}(=15 \times 2 \pi \mathrm{rad} / \mathrm{s})$ の 2 つ自転速度にて得られた実験データか ら, 式 (22) により算出した不釣り合い力の振幅 $U$ とその位相 $\phi_{u}$ から, 既知おもりの大きさ $m_{\text {add }}$ と付加角度 $\phi_{m}$ を推定し，実際のおもりと比較した．実験は不釣り合い重りとして，9.5 g のおもりを基準面から 0，45，90 $\operatorname{deg}$ の位置に付加し行った. 表 6 に比較結果を示寸. 付加質量の大きさ $m_{\text {add }}$ に関しては各条件での誤差の平均 值から, 誤差約 $10 \%$ 程度の精度で推定できていることが分かる. この誤差の原因としては, 付加質量の実測值 の計測誤差や修正面までの半径 $r$ のばらつきなどが考えられる. また, 付加質量の位相 $\phi_{m}$ に関しては, 平均 $+1.3 \mathrm{deg}$ 程度の誤差であり, 精度よく推定できていることが分かる. これらの結果から提案する外力推定手法が 良好な推定精度を持っていることが確認できる.

Table 6 Difference between actual added weight and estimated value

\begin{tabular}{c|c||c|c|c|c}
\hline \hline Actual $m_{\text {add }}$ & Actual $\phi_{m}$ & Estimated $m_{\text {add }}$ & Error & Estimated $\phi_{m}$ & Error \\
\hline \hline \multirow{3}{*}{$9.5 \mathrm{~g}$} & $0 \mathrm{deg}$ & $8.897 \mathrm{~g}$ & $-0.603 \mathrm{~g}$ & $0.065 \mathrm{deg}$ & $+0.065 \mathrm{deg}$ \\
\cline { 2 - 6 } & $45 \mathrm{deg}$ & $9.426 \mathrm{~g}$ & $-0.074 \mathrm{~g}$ & $45.605 \mathrm{deg}$ & $+0.605 \mathrm{deg}$ \\
\cline { 2 - 6 } & $90 \mathrm{deg}$ & $7.814 \mathrm{~g}$ & $-1.686 \mathrm{~g}$ & $93.279 \mathrm{deg}$ & $+3.279 \mathrm{deg}$ \\
\hline \hline
\end{tabular}




\section{5. 結 言}

回転機械の回転軸が様々な軌道で振れ回るときにロータ系に作用する外力を解析するため，任意の回転軸の軌 道を AMB に実装した電流を制御するコントローラから生成し, その軌道に高精度に追従した上で, ロータ系に 作用する外力を推定可能な実験装置の開発し, 以下の結論を得た.

1. 弾性ロータのように周波数応答上に弾性モードピークが生じる制御対象においては, フィードバックコント ローラとしてノッチフィルタを用いてループ整形を行うことが, 制御帯域での良好な制御と系の安定性を両 立するために有効である.

2. 逆モデル型外乱オブザーバのフィルタ $F(s)$ は，外乱オブザーバの外乱推定・相殺性能と制御系の安定性に 大きく影響する，性能と安定性の両立を実現するためには，制御帯域では $F(s) \approx 1$ に近い特性を持ち，高次 モードのピーク位置近傍では $F(s) \hat{G}_{P}^{-1}(s) G_{P}(s)$ のゲインが小さいような特性をもつフィルタを用いること が有効である.

3. 上記 2 つのコントローラを含む $\mathrm{AMB} ・$ ロータ系の目標軌道追従システムを構築し, 実験にて良好な任意ふ れまわり軌道への追従制御を実現した. しかしながら, センサ部のランナウトによる振動が確認されたため, 制御系に繰り返し制御や周期外乱と同じ次数の 2 次フィルタなどを実装し，制御系でランナウトを除去する ことが必要となる.

4. 逆モデル型外乱オブザーバにより推定された外乱信号に対して, オフラインで適切な処理を行うことにより 外力を推定するという外力推定法を構築した.

5. 本研究で開発した装置により, 回転軸の任意軌道に対する追従制御と, 外力推定を行ったところ, 目標軌道 に対する誤差の標準偏差が約 $0.01 \mathrm{~mm}$ とサブマイクロオーダーの精度で追従でき，そして，外力として既知 の重りによって発生させた不釣り合い力を誤差 10\%程度の精度で推定できることを確認した。

6. 任意軌道への追従制御と不釣り合い力を推定する実験で良好な推果が得られたことから，他の外力推定に援 用可能だと考えられる．そこで，不釣り合い力以外の外力である，シール接触力やロータダイナミック流体 カへの援用を計画しているが，そのときセンサ部のランナウト除去が課題となる．本論文では，2 つの回転 速度の測定結果から差分をとり除去したが，前述の外力は回転数に依存するため（Ikemoto et al., 2016）, この 手法は適用できない. 制御系においてランナウトは回転速度に同期した周期外乱として観測されるので，項 目 4 と同様に，制御系でランナウトを除去して推定することが必要である.

\section{文献}

Andrés, L. S. and Delgado, A., A novel bulk-flow model for improved predictions of force coefficients in grooved oil seals operating eccentrically, Journal of engineering for gas turbines and power, Vol. 134, No.5 (2012), p. 052509.

Andrés, L. S., Den, S. and Jeung, S. H., Transient response of a short-length ( $\mathrm{L} / \mathrm{D}=0.2)$ open-ends elastically supported squeeze film damper: centered and largely off-centered whirl motions, Journal of Engineering for Gas Turbines and Power Vol. 138, No. 12 (2016), p.022502.

Andrés, L. S. and Jeung, S. H., Experimental performance of an open ends, centrally grooved, squeeze film damper operating with large amplitude orbital motions, Journal of Engineering for Gas Turbines and Power Vol. 137, No. 3 (2015), p.022502.

Andrés, L. S. and Jeung, S. H., Orbit-model force coefficients for fluid film bearings: a step beyond linearization, Journal of Engineering for Gas Turbines and Power Vol. 138, No. 2 (2016), p.022502.

Araki, M. and Taguchi, H., Two-degree-of-freedom PID controllers, International Journal of Control, Automation, and Systems, Vol. 1, No. 4 (2003), pp. 401-411.

Chen, M. and Knospe, R. C., Feedback linearization of active magnetic bearings: current-mode implementation, IEEE/ASME Transaction on Mechatronics, Vol. 10, No. 6 (2005), pp. 632-639.

江口真人, 丸田芳幸, 後藤彰, 磁気軸受搭載ロータダイナミクステストスタンドによるターボ機械の特性評価, ターボ機械, Vol. 30, No. 2 (2002), pp.99-108. 
Ikemoto, A., Sakamoto, K., Inoue, T. and Uchiumi, M., Analytical investigation on the rotational speed dependence of the rotordynamic fluid force: the case of concentric circular whirl in the annular plain seal, Proceedings of ASME International Mechanical Engineering Congress and Exposition (2016), p. V007T09A011.

井上剛志，石田幸男，村上新，鉛直支持された磁気軸受・ロータ系の非線形振動解析と実験(制御力の遅れを考 慮した場合), 日本機械学会論文集 C 編, Vol. 71，No.701 (2005), pp.2106-2112.

兼森祐治, 岩壼卓三, 長い平行環状シールの動的流体力に関寸る実験的研究 回転体がコニカルモードでふれれ まわり運動する場合に発生する動的流体力, 日本機械学会論文集 C 編, Vol. 55, No. 520 (1989), pp.29742981.

Kato, J., Takagi, K. and Inoue, T., On the stability analysis of active magnetic bearing with parametric uncertainty and position tracking control, Proceedings of ASME International Mechanical Engineering Congress and Exposition (2016), p. V04AT05A004.

Lindlau, D. J. and Knospe, R. C., Feedback linearization of an active magnetic bearing with voltage control, IEEE Transactions on control systems technology, Vol. 10, No. 1 (2002), pp.21-31.

西嶋規世, 遠藤彰, 山口和幸, 回転機械の軸シールで発生する不安定流体力の数值解析 (シール長さとギャッ プの影響)，日本機械学会論文集，Vol. 80， No. 816 (2014), DOI:10.1299/transjsme.2014fe0226.

野波健蔵, 平田光男, 西村秀和, MATLAB による制御設計 (1998).

Noshadi, A., Shi, J., Lee, S. W., Shi, P. and Kalam, A., Robust control of an active magnetic bearing system using Ho and disturbance observer-based control, Journal of Vibration and Control, Vol. 1, No. 14 (2015), p.077546315602421.

杉江俊治, 清水一憲, 井村順一，厳密な線形化手法を用いた $\mathrm{H} \infty$ 制御とその磁気浮上系への応用，システム制 御情報学会論文誌, Vol. 6, No. 1 (1993), pp. 57-63.

電気学会編, 磁気浮上と磁気軸受 (1993).

日本機械学会編, 磁気軸受の基礎と応用 (1995).

Tokunaga, Y., Inoue, H., Hiromatsu, J., Iguchi, T., Kuroki, Y. and Uchiumi, M., Rotordynamic characteristics of floating ring seals in rocket turbopumps, International Journal of Fluid Machinery and Systems, Vol. 9, No. 3 (2016), pp. 194204.

Yun, H. and Brennen, C. E., Fluid flow equations for rotordynamic flows in seals and leakage paths, Journal of fluids engineering, Vol.124, No.1 (2002), pp.176-181.

\section{References}

Andrés, L. S. and Delgado, A., A novel bulk-flow model for improved predictions of force coefficients in grooved oil seals operating eccentrically, Journal of engineering for gas turbines and power, Vol. 134, No.5 (2012), p. 052509.

Andrés, L. S., Den, S. and Jeung, S. H., Transient response of a short-length $(\mathrm{L} / \mathrm{D}=0.2)$ open-ends elastically supported squeeze film damper: centered and largely off-centered whirl motions, Journal of Engineering for Gas Turbines and Power Vol. 138, No. 12 (2016), p.022502.

Andrés, L. S. and Jeung, S. H., Experimental performance of an open ends, centrally grooved, squeeze film damper operating with large amplitude orbital motions, Journal of Engineering for Gas Turbines and Power Vol. 137, No. 3 (2015), p.022502.

Andrés, L. S. and Jeung, S. H., Orbit-model force coefficients for fluid film bearings: a step beyond linearization, Journal of Engineering for Gas Turbines and Power Vol. 138, No. 2 (2016), p.022502.

Araki, M. and Taguchi, H., Two-degree-of-freedom PID controllers, International Journal of Control, Automation, and Systems, Vol. 1, No. 4 (2003), pp. 401-411.

Chen, M. and Knospe, R. C., Feedback linearization of active magnetic bearings: current-mode implementation, IEEE/ASME Transaction on Mechatronics, Vol. 10, No. 6 (2005), pp. 632-639.

Eguchi, M., Maruta, Y. and Goto, A., Estimation method of turbomachinery properties from a rotordynamic test stand using magnetic bearings, Turbomachinery, Vol. 30, No. 2 (2002), pp.99-108 (in Japanese). 
Ikemoto, A., Sakamoto, K., Inoue, T. and Uchiumi, M., Analytical investigation on the rotational speed dependence of the rotordynamic fluid force: the case of concentric circular whirl in the annular plain seal, Proceedings of ASME International Mechanical Engineering Congress and Exposition (2016), p. V007T09A011.

Inoue, T., Ishida, T. and Murakami, S., Nonlinear vibration analysis and experiments of a vertical rigid rotor-magnetic bearing system (case considering the delay of control force), Transactions of the Japan Society of Mechanical Engineers, Series C, Vol. 71, No.701 (2005), pp.2106-2112 (in Japanese).

Kanemori, Y. and Iwatsubo, T., Experimental study of dynamical characteristics of a long annular seal: force and moment due to conical whirl rotation, Transactions of the Japan Society of Mechanical Engineers, Series C, Vol. 55, No. 520 (1989), pp. 2974-2981 (in Japanese).

Kato, J., Takagi, K. and Inoue, T., On the stability analysis of active magnetic bearing with parametric uncertainty and position tracking control, Proceedings of ASME International Mechanical Engineering Congress and Exposition (2016), p. V04AT05A004.

Lindlau, D. J. and Knospe, R. C., Feedback linearization of an active magnetic bearing with voltage control, IEEE Transactions on control systems technology, Vol. 10, No. 1 (2002), pp.21-31.

Nishijima, N., Endo, A. and Yamaguchi, K., Numerical investigation on fluid force acting on shaft seals in turbo-machines (Effect of seal length and gap), Transactions of the JSME (in Japanese), Vol. 80 , No. 816 (2014), DOI:10.1299/transjsme.2014fe0226.

Nonami, K., Hirata, M. and Nishimura, H., Control system design by MATLAB, Tokyo Denki University Press (1998) (in Japanese).

Noshadi, A., Shi, J., Lee, S. W., Shi, P. and Kalam, A., Robust control of an active magnetic bearing system using Hळ and disturbance observer-based control, Journal of Vibration and Control, Vol. 1, No. 14 (2015), p.077546315602421.

Sugie, T., Shimizu, K. and Imura, J., H $\infty$ control with exact linearization and its application to magnetic levitation systems, Transactions of the Institute of Systems, Control and Information Engineers, Vol. 6, No. 1 (1993), pp. 57-63, (in Japanese).

The Institute of Electrical Engineers of Japan ed., Magnetic levitation and magnetic bearings, CORONA Publishing co.,ltd. (1993) (in Japanese).

The Japan Society of Mechanical Engineers ed., The basis and application of the magnetic bearings, Yokendo co.,Itd.(1995) (in Japanese).

Tokunaga, Y., Inoue, H., Hiromatsu, J., Iguchi, T., Kuroki, Y. and Uchiumi, M., Rotordynamic characteristics of floating ring seals in rocket turbopumps, International Journal of Fluid Machinery and Systems, Vol. 9, No. 3 (2016), pp. 194204.

Yun, H. and Brennen, C. E., Fluid flow equations for rotordynamic flows in seals and leakage paths, Journal of fluids engineering, Vol.124, No.1 (2002), pp.176-181. 